\title{
Consolidation of sediments by glaciers: relations between sediment geotechnics, soft-bed glacier dynamics and subglacial ground-water flow
}

\author{
G. S. Boulton AND K. E. DobBiE \\ Department of Geology and Geophysics, Grant Institute, University of Edinburgh, Edinburgh EH9 37W, Scotland
}

\begin{abstract}
A theory of subglacial consolidation is developed which shows how the meltwater flux beneath a glacier leaves a consolidation signature from which many important glacier-dynamic properties can be inferred. Conditions under which water is discharged through channels or in a thin film at the ice-bed interface or by ground-water flow are discussed, and it is concluded that glaciers flowing over aquifers of high transmissibility can induce deep circulation patterns quite different from non-glacial circulation. Examples of glacial pre-consolidation profiles in sediments from The Netherlands and England are used to illustrate how basal melting rates, subglacial ground-water flow patterns, ice overburden, basal shear stress, ice-surface profile and the amount of sediment removed by erosion can be inferred.
\end{abstract}

\section{INTRODUCTION}

The late Cenozoic ice age has been characterized by cyclical phases of ice-sheet growth and decay in Europe and North America which have periodically loaded the Earth's crust by up to $30000 \mathrm{kPa}$. Expanding glaciers compress the sediments over which they flow by consolidating them to greater densities. Even though these sediments swell on glacier retreat, they still retain part of the glacial consolidation. Such a sediment, which has a density greater than it would have under the load to which it is currently subjected, because of some greater

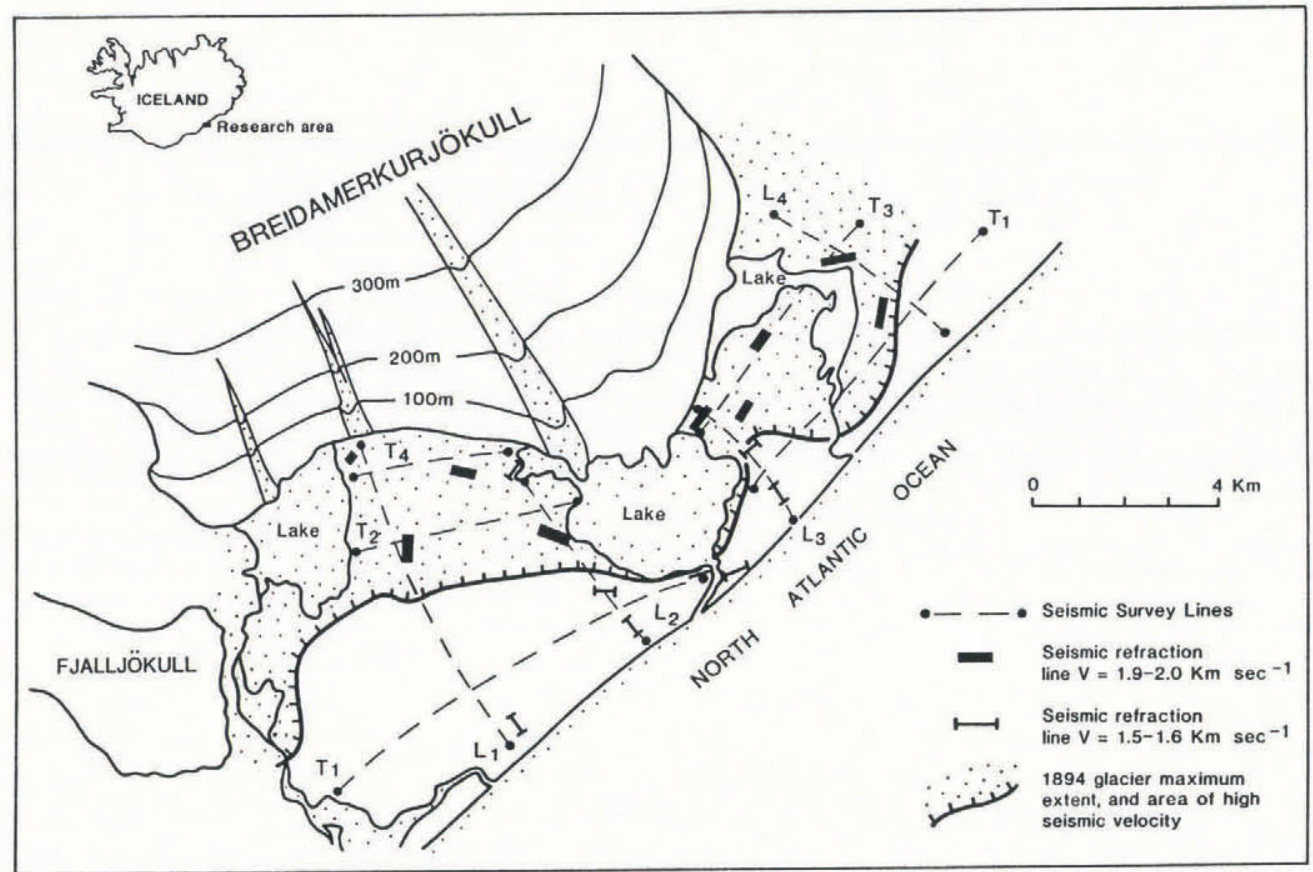

Fig. 1. Evidence of a consolidation footprint left by the Little Ice Age advance of Breidamerkurjökull, Iceland. Seismic velocities are significantly higher in the area consolidated by glacier expansion than in the unglaciated area $\left(1.9-2.0 \mathrm{~km} \mathrm{~s}^{-1}\right.$ compared with $1.5-1.6 \mathrm{~km} \mathrm{~s}^{-1}$ ). The sedimentary sequences in the two areas are similar. 
load in the past, is termed overconsolidated (Casagrande, 1936). The consolidation footprint of glaciation is illustrated in Figure 1 where sediments in an area of 19 th century glacier expansion display a seismic velocity 1.25 times greater than sediments of similar character lying immediately beyond the maximum extent of the glacier, reflecting the greater glacially induced density of the over-ridden sequence.

We suggest that the magnitudes and patterns of consolidation in fine-grained sediments which have lain beneath glaciers reflect patterns of glacial loading, subglacial deformation and water flow, and thus we believe that the state of consolidation of fine-grained sediments can be used as a guide to important dynamic properties of former ice sheets and some aspects of subglacial drainage. There is not a simple relationship between consolidation state and ice load, as some have suggested.

The flow of meltwater beneath glaciers has normally been supposed to occur within a thin subglacial zone, either within channels immediately beneath the glacier or as a thin sheet flow between the glacier sole and bed. We demonstrate significant discharges of water into subglacial aquifers and glacial control of meltwater flow within very large ground-water reservoirs.

An earlier paper (Boulton and Hindmarsh, 1987) discussed the conditions under which subglacial sediments deform. The argument presented here is based on that approach, but complements and extends it by discussing the processes which determine the magnitude and pattern of glacial overconsolidation, which can be measured, and used to reconstruct the properties of former ice sheets and their beds, including deformation of till and large-scale patterns of subglacial water flow.

\section{NOTATION}

$C$
$C_{\mathrm{c}}$
$\phi$
$g$
$H$
$k$
$k_{\mathrm{a}}$
$m$
$n$
$p$
$p_{\mathrm{i}}$
$p^{\prime}$
$p_{\mathrm{w}}$
$p_{\mathrm{c}}^{\prime}$
$p_{\mathrm{a}}$
$p_{0}$
$p^{\prime}$

C

$\phi$

$g$

H

$k$

$k_{\mathrm{a}}$

$m$

$n$

$p$

$p_{\mathrm{i}}$

$p^{\prime}$

$p_{\mathrm{w}}$

$p_{\mathrm{c}}^{\prime}$

$p_{\mathrm{a}}^{\prime}$

$p_{0}^{\prime}$

$\left(\partial p^{\prime} / \partial z\right)_{\mathrm{g}}$ $\psi$ $\rho_{\mathrm{w}}$

$S$

$\sigma$

$t$

$t_{\mathrm{A}}$

$t_{\mathrm{e}}$

$T$

$\tau_{\mathrm{b}}$

$x$

$X_{0}$

$X_{1}$
Density of water

Sediment yield strength in shear

Applied stress

Till-stratum thickness

Thickness of the deforming horizon in the sediment (tectonic A-horizon)

Thickness of sediment removed by erosion

Thickness of the aquifer

Shear stress at the base of the glacier

Horizontal distance from the ice divide

Distance from the ice divide to the upglacier extremity of the melting zone Distance from the ice divide to the downglacier extremity of the melting zone.

\section{GLAGIAL GONSOLIDATION}

Clastic sediments consist of inccmpressible mineral particles with intervening vcids filled with water. The effective pressure $\left(p^{\prime}\right)$ at any point witl.in the sediment is the difference between the total pressure $(p)$ and the water pressure in the voids $\left(p_{\mathrm{w}}\right)$ :

$$
p^{\prime}=p-p_{\mathrm{w}} \text {. }
$$

If a sediment sample is not loaded, and there is no water flow into or out of the sample, there will be no potential pressure component (i.e. the vertical potential gradient $\partial \psi / \partial z$ is zero), and the vertical effective pressure gradient will be gravitational:

$$
\frac{\partial p^{\prime}}{\partial z}=\frac{\partial p}{\partial z}-\frac{\partial p_{\mathrm{w}}}{\partial z}
$$

Since

$$
\frac{\partial p}{\partial z}=\rho g
$$

and

and

$$
\frac{\partial p_{\mathrm{w}}}{\partial z}=\rho_{\mathrm{w}} g
$$

$$
\rho=n \rho_{\mathrm{w}}+(1-n) \rho_{\mathrm{s}}
$$

(where $\rho$ is bulk density, $\rho_{\mathrm{w}}$ and $\rho_{\mathrm{s}}$ the density of water and solids, respectively, $n$ is the porosity and $g$ is the acceleration due to gravity) from Equations (1)-(5)

$$
\partial p^{\prime} / \partial z=(1-n)\left(\rho_{\mathrm{s}}-\rho_{\mathrm{w}}\right) g=\left(\partial p^{\prime} / \partial z\right)_{\mathrm{g}}
$$

where $\left(\partial p^{\prime} / \partial z\right)_{\mathrm{g}}$ is the gravitational effective pressure gradient.

When subjected to an external load, on the other hand, the mineral grains will respond by becoming more tightly packed, provided that the interstitial water is able to escape. This is the process of consolidation (Fig. 2). The additional compressive stress $(\sigma)$ applied to the sediment sample will initially be borne entirely by the interstitial water and thus the water pressure at the sediment surface will be equal to the applied stress:

$$
p_{\mathrm{w}}=\sigma \text {. }
$$

This generates a potential pressure $(\psi)$. If the sample is permitted to drain at the base, where the potential pressure of water is zero, a vertical potential water pressure gradient $\partial \psi / \partial z$ will develop. 


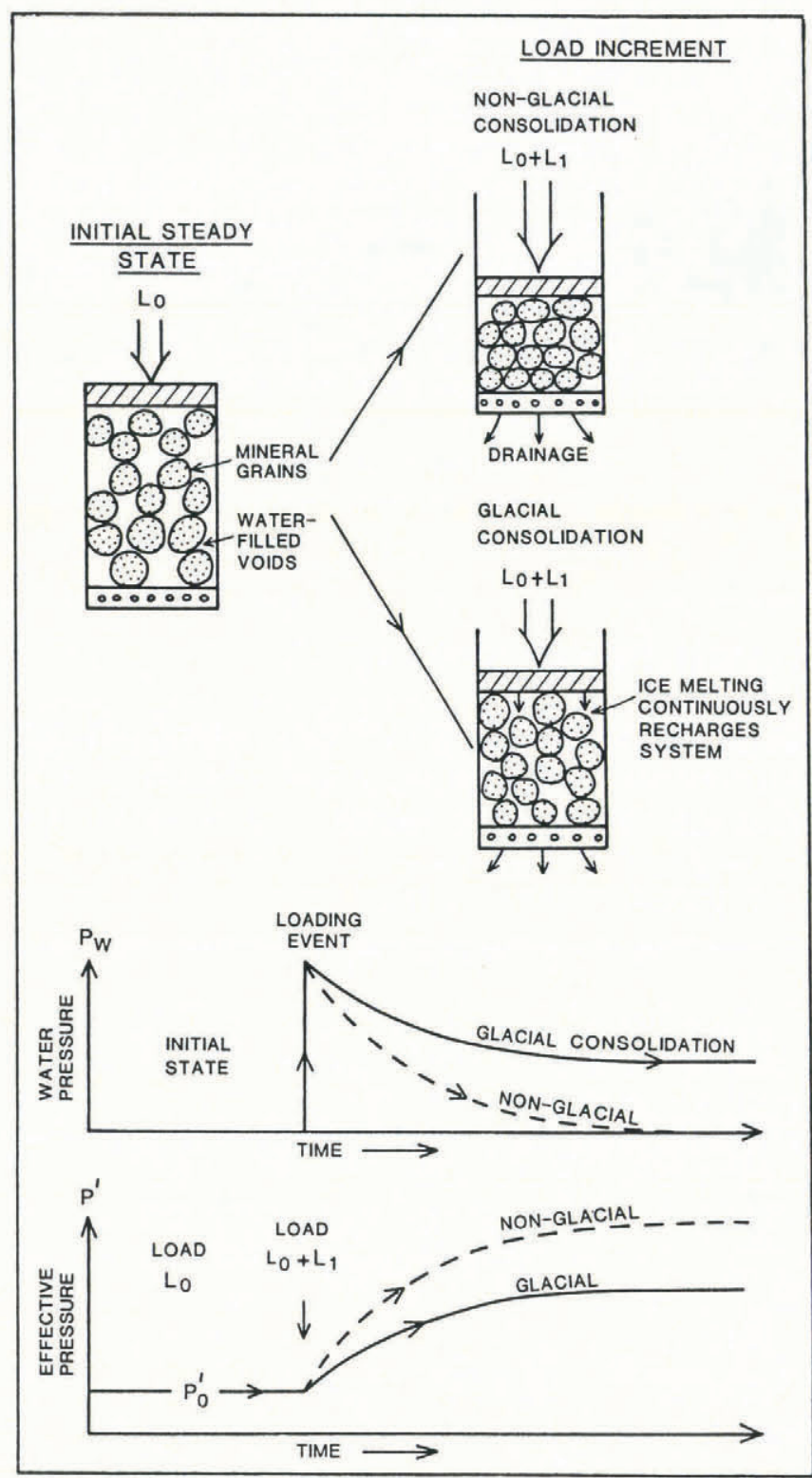

Fig. 2. Glacial and non-glacial consolidation. A load increment on a granular sediment in a pressure cell sets up a potential pressure in the interstitial water. This causes water to flow out of the cell and permits grain-packing to improve until all the additional load is borne by the grains and potential pressure has decayed to zero. Beneath a melting glacier, there is a continuous water flux into the sediment. Discharge from this water requires a permanent potential gradient. Thus, the effective pressure (load pressure minus water pressure) will be smaller than in the case of non-glacial consolidation benenath a similar load.

Under these conditions

$$
\frac{\partial p_{\mathrm{w}}}{\partial z}=\frac{\partial \psi}{\partial z}+\rho_{\mathrm{w}} g .
$$

Substituting this into Equation (2) gives

$$
\frac{\partial p^{\prime}}{\partial z}=\left(\frac{\partial p}{\partial z}-\rho_{\mathrm{w}} g\right)-\frac{\partial \psi}{\partial z}
$$

Substituting Equation (3) into Equation (8) gives

$$
\begin{aligned}
\frac{\partial p^{\prime}}{\partial z} & =\left(\rho_{\mathrm{g}}-\rho_{\mathrm{w}} g\right)-\frac{\partial \psi}{\partial z} \\
& =\left(\rho-\rho_{\mathrm{w}}\right) g-\frac{\partial \psi}{\partial z}
\end{aligned}
$$

Substituting the righthand side of Equation (5) for $\rho$ in Equation (9) gives

$$
\begin{aligned}
\frac{\partial p^{\prime}}{\partial z} & =\left\{\left[n \rho_{\mathrm{w}}+(1-n) \rho_{\mathrm{s}}\right]-\rho_{\mathrm{w}}\right\} g-\frac{\partial \psi}{\partial z} \\
& =(1-n)\left(\rho_{\mathrm{s}}-\rho_{\mathrm{w}}\right) g-\frac{\partial \psi}{\partial z}
\end{aligned}
$$

By comparing this with Equation (6), for the gravitational effective-pressure component, we derive the total effective-pressure component:

$$
\frac{\partial p^{\prime}}{\partial z}=\left(\frac{\partial p^{\prime}}{\partial z}\right)_{\mathrm{g}}-\frac{\partial \psi}{\partial z}
$$

The potential gradient will cause water to escape at a rate $\nu$ given by Darcy's law

$$
\nu=\frac{-k}{\rho_{\mathrm{w}} g} \frac{\partial \psi}{\partial z}
$$

where $k$ is intrinsic permeability.

As water escapes from the sample, it is able to consolidate and the additional stress $(\sigma)$ is progressively transferred from the interstitial water to the mineral-grain skeleton. Water pressure decreases and the effective pressure correspondingly increases until the potential gradient is reduced to zero (Fig. 2). No further water is expelled and consolidation is complete.

From the beginning to the end of the process, effective pressure gradients change

from

$$
\begin{aligned}
& \frac{\partial p^{\prime}}{\partial z}=\left(\frac{\partial p^{\prime}}{\partial z}\right)_{\mathrm{g}}-\frac{\partial \psi}{\partial z} \\
& \frac{\partial p^{\prime}}{\partial z}=\left(\frac{\partial p^{\prime}}{\partial z}\right)_{\mathrm{g}} \text { as } \quad \frac{\partial \psi}{\partial z} \rightarrow 0 .
\end{aligned}
$$

to

The beds of most glaciers in temperate regions and large parts of the beds of polar ice sheets are actively melting as a consequence of geothermal heating and by frictional heating due to the movement of the glacier. Consolidation of sediments beneath a melting glacier must therefore take place in the presence of a water flux from the glacier sole. On loading by a melting glacier, a sediment will consolidate as before, but, in areas where there are no channels, the equilibrium consolidated state must still permit basal meltwater to drain through the sediment at a rate fast enough to discharge basal meltwater (Fig. 2). The final water pressure immediately beneath the glacier will not merely be a static gravitational pressure but will include a component of potential pressure resulting from the potential gradient required to discharge basal meltwater at a rate $m$. From Darcy's law,

$$
m=\frac{-k}{\rho_{\mathrm{w}} g} \frac{\partial \psi}{\partial z} .
$$

The final effective pressure will therefore be less than it would be under non-glacial consolidation (Fig. 2) and the vertical effective pressure gradient will be 


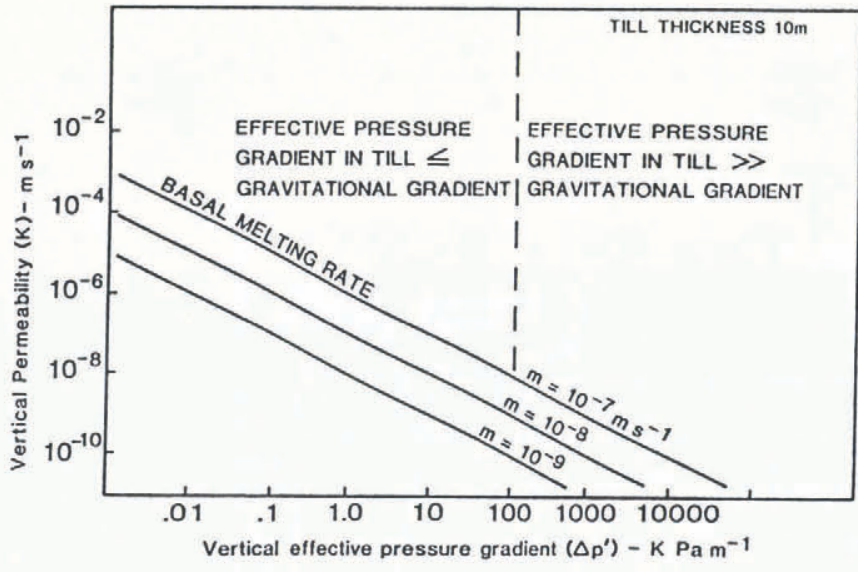

Fig. 3. The effective pressure gradient required in sediments of different permeability to discharge meltwater vertically through a subglacial bed at rates varying from $10^{-1} \mathrm{~m} \mathrm{~s}^{-1}$ to $10^{-9} \mathrm{~m} \mathrm{~s}^{-1}$. The vertical gravitational gradient of effective pressure due to the self-weight of sediment grains and interstitial water is normally about $10 \mathrm{kPa} \mathrm{m}^{-1}$. Thus, sediment with permeabilities smaller than about $10^{-8}-10^{-10} \mathrm{~m} \mathrm{~s}^{-1}$ will tend to develop effective pressure gradients significantly larger than the gravitational gradient.

$$
\frac{\partial p^{\prime}}{\partial z}=\left(\frac{\partial p^{\prime}}{\partial z}\right)_{\mathrm{g}}-\frac{\partial \psi}{\partial z}=(1-n)\left(\rho_{\mathrm{s}}-\rho_{\mathrm{w}}\right) g-\frac{m \rho_{\mathrm{w}} g}{k} .
$$

The relative magnitudes of the gravitational component of effective pressure, $\left(\partial p^{\prime} / \partial z\right)_{\mathrm{g}}=(1-n)\left(\rho_{\mathrm{s}}-\rho_{\mathrm{w}}\right) g$, and the potential component $\partial \psi / \partial z=m \rho g /-k$ will be determined by the permeability of the sediment. Figure 3 shows the magnitude of the effective pressure gradient $\partial p^{\prime} / \partial z$ for a range of sediment permeabilities and a range of typical subglacial melting rates $(m)$. The gravitational component is normally about $10 \mathrm{kPa} \mathrm{m}^{-1}$. Where permeabilities are less than $10^{-8}-10^{-10} \mathrm{~m} \mathrm{~s}^{-1}$, the potential gradient required to discharge meltwater is much greater, and results in a vertical effective pressure gradient well in excess of the gravitational gradient.

However, permeability $(k)$ and porosity $(n)$ are dependent on effective pressures and therefore decrease downwards. To maintain the discharge

$$
m=\left(\frac{-k}{\rho_{\mathrm{w}} g} \frac{\partial \psi}{\partial z}\right),
$$

$\partial \psi / \partial z$ must increase downwards, and thus the component of $\partial p^{\prime} / \partial z$ due to the potential gradient will show a non-linear increase with depth. Reduction of porosity with depth also gives a non-linear increase in the gravitational component of effective pressure.

Relationships between porosity and effective pressure and permeability and effective pressure can be empirically determined from the consolidation test (Boulton and others, 1974).

Porosity is given by:

$$
\left(\frac{n}{1-n}\right) \log p^{\prime}=C_{\mathrm{c}}
$$

where $C_{\mathrm{c}}$ is a constant defined by this relationship and known as the compression index.
Permeability is given by:

$$
\ln k=\ln k_{0}+b\left(p-p_{\mathrm{w}}\right)
$$

where $b$ is a constant.

Substituting Equations (16) and (17) into Equation (15) and solving for $\partial p^{\prime} / \partial z$ gives

$$
\frac{\partial p}{\partial z}=\frac{\log p^{\prime}}{\log p^{\prime}+C}\left(\rho_{\mathrm{s}}-\rho_{\mathrm{w}}\right) g-\frac{m \rho_{\mathrm{w}} g \mathrm{e}^{-b p^{\prime}}}{k_{0}} .
$$

As Boulton and Hindmarsh (1987) have noted, the disequilibrium between ice pressure and water pressure at the glacier sole will cause ice to invade the intergranular pores in the sediment. Deep penetration will be prevented by melting at the glacier sole even in very open sediments but, in sediments of the low permeability discussed here, penetration will be insignificant.

\section{SUBGLACIAL GROUND-WATER FLOW PAT. TERNS}

Meltwater produced at the base of a glacier is discharged by one or a combination of routes:

By flow in a sheet between a glacier and its bed.

By flow in channels between the glacier and its bed.

By ground-water flow through subglacial sediments and rocks.

We initially consider the meltwater discharged by ground-water flow as if this were the only discharge route, and then consider how meltwater might be partitioned between ground water and the other routes.

The character and geometry of subglacial sediments are fundamental determinants of the nature and rate of ground-water drainage, and therefore of the rate and degree of consolidation. It is common for a glacier in lowland terrain to be underlain by till, a relatively finegrained sediment of low permeability. We consider situations where till, or any other low-permeability sediment, is underlain by a highly permeable aquifer (the one-dimensional case) and by an aquiclude (the twodimensional case).

\section{The one-dimensional case}

In this case the sub-till aquifer acts as a drain for the overlying low-permeability till and water drains vertically downwards from the glacier sole, through the till and into the aquifer.

Figure 4 shows a very simple case in which a stratum of high hydraulic transmissibility underlies the whole of a subglacial till stratum, being recharged by meltwater which flows through the till and discharging that meltwater into the proglacial zone. We assume that the water pressure at the top of the aquifer immediately beyond the glacier terminus will be zero. Assuming a constant specific basal melt rate $(m)$ in a zone of melting beginning at $X_{0}$ in an aquifer of constant permeability $\left(k_{\mathrm{a}}\right)$ and thickness $(T)$, the horizontal, two-dimensional, 


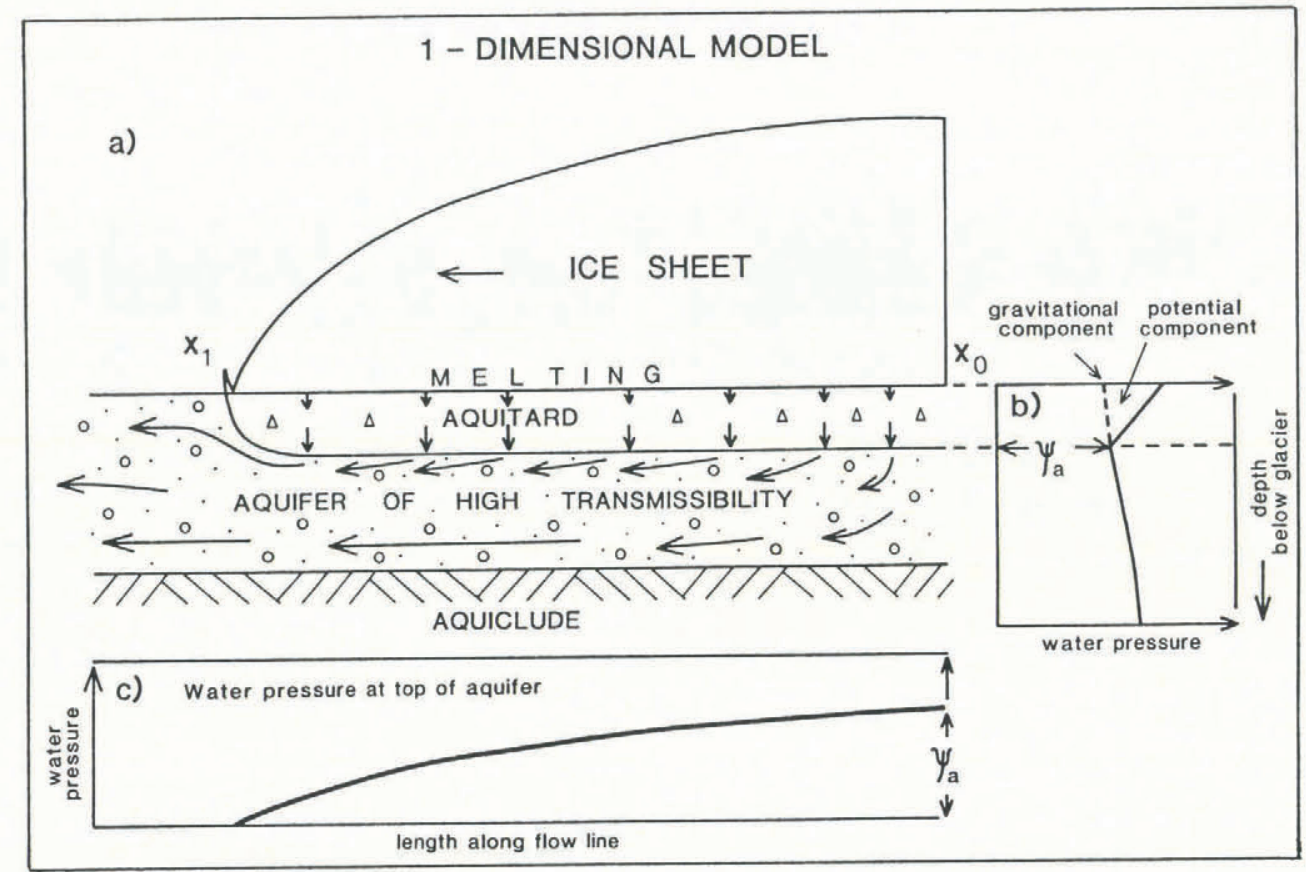

Fig. 4. One-dimensional drainage model of subglacial meltwater through an aquitard (till or other fine-grained sediment) into an underlying aquifer. There is a vertical influx of water at the top of the till and water is driven vertically through the aquitard by a potential gradient inversely proportional to permeability. Flow through the aquifer drain is horizontal and the vertical water-pressure gradient in it is due solely to the weight of water. The horizontal potential gradient in the aquifer required to discharge meltwater sets the value of the potential $\left(\psi_{\mathrm{a}}\right)$ at the base of the aquitard. The potential pressure at the base of the glacier will be $\psi_{\mathrm{a}}+\Delta \psi$, where $\Delta \psi$ is the potential drop across the aquitard.

subglacial discharge in the aquifer $\left(Q_{\mathrm{T}}\right)$ at any point $(x)$ will be

$$
Q_{\mathrm{T}}=\left(x-X_{0}\right) m \text {. }
$$

From Darcy's law, the horizontal potential gradient $\partial \psi / \partial x$ in the aquifer required to drive this discharge will be:

$$
\frac{\partial \psi}{\partial x}=\left(x-X_{0}\right) m \rho_{\mathrm{w}} g .
$$

Assuming that subglacial melting extends to the glacier terminus $\left(x=X_{1}\right)$, the potential pressure at the top of the aquifer at the terminus will be zero and, if we assume that subglacial melting extends to the terminus, inserting the discharge from Equation (19) into Darcy's law gives the potential gradient at the terminus

$$
\frac{\partial \psi}{\partial x}=\frac{\left(X_{1}-X_{0}\right)}{-k_{\mathrm{a}} T} m \rho_{\mathrm{w}} g
$$

and the potential gradient at any point will be

$$
\frac{\partial \psi}{\partial x}=\frac{\left(x-X_{0}\right) m \rho_{\mathrm{w}} g}{-k_{\mathrm{a}} T} .
$$

The potential at the top of the aquifer $\left(\psi_{\mathrm{a}}\right)$ at any point is given by

$$
\begin{aligned}
\psi_{a} & =\int_{x}^{x_{0}} \frac{\partial \psi}{\partial x}=\int_{x}^{x_{0}} \frac{\left(x-X_{0}\right)}{k T} m \rho_{\mathrm{w}} g \partial x \\
{\left[\psi_{a}\right] } & =\frac{m \rho_{\mathrm{w}} g}{k T}\left[\frac{x^{2}}{2}-X_{0} x\right]_{x}^{X_{0}} .
\end{aligned}
$$

In the till overlying the aquifer, a vertical waterpressure potential gradient will develop to ensure vertical discharge of basal meltwater through the till so that, from Darcy's law:

$$
\frac{\partial \psi}{\partial z}=\frac{m \rho_{\mathrm{w}} h}{-k} .
$$

The vertical effective pressure gradient in the till will be given by Equation (18).

For a given potential pressure at the top of the underlying aquifer $\left(\psi_{\mathrm{a}}\right)$ and till stratum thickness $(t)$ the effective pressure at the glacier sole $\left(p_{0}{ }^{\prime}\right)$ will be (Fig. 5):

$$
p_{0}{ }^{\prime}=p_{\mathrm{i}}-\left[\psi_{\mathrm{a}}-t\left(n \rho_{\mathrm{w}}+\frac{m}{k}\right)\right]
$$

where $p_{\mathrm{i}}$ is the ice pressure and $\rho_{\mathrm{w}} n g t$ and $m t / k$ are the gravitational and potential components of water pressure in the till, respectively.

Figure 5 also illustrates the following important relationship:

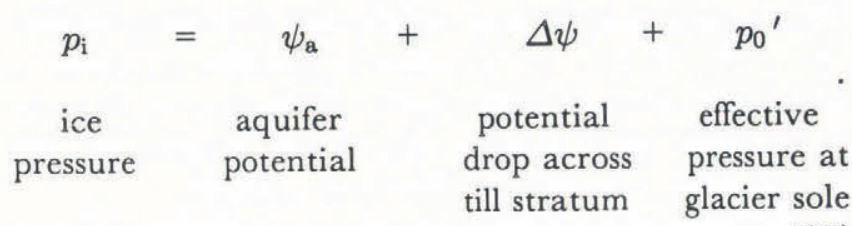

Where permeability is low $\left(<10^{-8}-10^{-10} \mathrm{~m} \mathrm{~s}^{-1}\right)$ (Figs 3 and $5 \mathrm{a})$, the potential drop across the stratum $(\Delta \psi)$ is large, and the vertical effective pressure gradient greatly exceeds the gravitational gradient. Where till permeability is relatively high $\left(>10^{-8}-10^{-10} \mathrm{~m} \mathrm{~s}^{-1}\right.$ ) (Figs 3 and 5b), $\Delta \psi$ is small and the effective pressure gradient is approximately gravitational. 


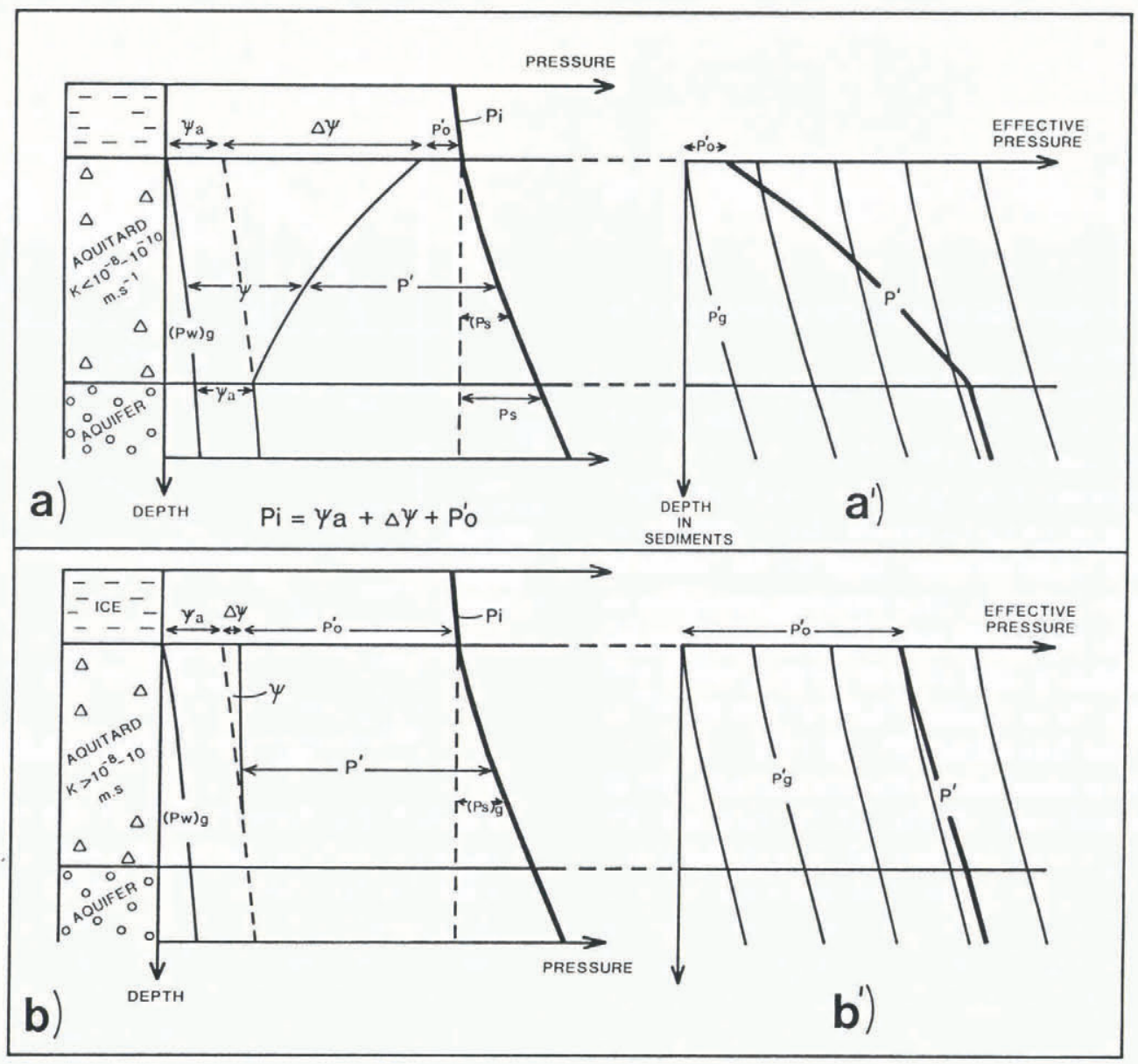

Fig. 5a-b. Pressure distributions in the one-dimensional case. $\left(p_{\mathrm{w}}\right)_{\mathrm{g}}=$ pressure due to weight of water, $\left(p_{\mathrm{s}}\right)_{\mathrm{g}}=$ pressure due to weight of sediment, $p_{\mathrm{i}}=$ ice pressure, $\psi=$ potential pressure of water, $\psi_{\mathrm{a}}=$ potential at the base of the aquitard, $\Delta \psi=$ potential drop across the aquitard, $p^{\prime}=$ effective pressure, $p_{0}{ }^{\prime}=$ effective pressure at glacier sole. The thickness of ice can be determined from $p_{\mathrm{i}}=\psi_{\mathrm{a}}+p_{0}{ }^{\prime}$. (a) Low-permeability aquitard $\left(k>10^{-8}-10^{-10} \mathrm{~m} \mathrm{~s}^{-1}\right)$ in which only a small potential pressure gradient is required to drive the meltwater though it contributes to a large vertical water-pressure gradient and produces an effective pressure gradient much larger than the gravitational gradient (Fig. $\left.5 a^{1}\right)$. The effective pressure at the glacier sole is small. (b) A more permeable aquitard $\left(k>10^{-8}-10^{-10} \mathrm{~m} \mathrm{~s}^{-1}\right)$ in which only a small potential gradient is required to drive the meltwater flux. As a result (Fig. $\left.5 b^{1}\right)$, the effective pressure gradient, is almost gravitational and the effective pressure at the glacier sole tends to be larger than in Figure $5 a$.

\section{Two-dimensional case}

In this case, subglacial till is directly underlain by an aquiclude, frequently impermeable bedrock, and water melting from the glacier sole must therefore be discharged within the till layer (Fig. 6). The discharge of water through such a till stratum must increase in the downglacier direction. If the permeability and thickness of the stratum remain constant, the potential gradient required to drive the flow will increase until the piezometric surface matches the glacier-surface slope. When this occurs, the effective pressure at the glacier bed will be zero, non-cohesive sediments will have no shear resistance and the glacier will be unstable (Boulton and Jones, 1979).

The ice pressure $\left(p_{\mathrm{i}}\right)$ on the glacier bed at any point along a longitudinal section through the ice sheet can be derived from Bødvarsson's (1955) plasticity solution for an ice sheet:

$$
\left(\frac{p_{\mathrm{i}}}{P}\right)^{2}+\left(\frac{x}{X_{1}}\right)^{2}=1
$$

where $P$ is the ice pressure at the ice divide.
For such an ice sheet, melting basally at a rate $m$, and with meltwater being discharged through an aquifer of thickness $T$ and permeability $k$, Boulton and others

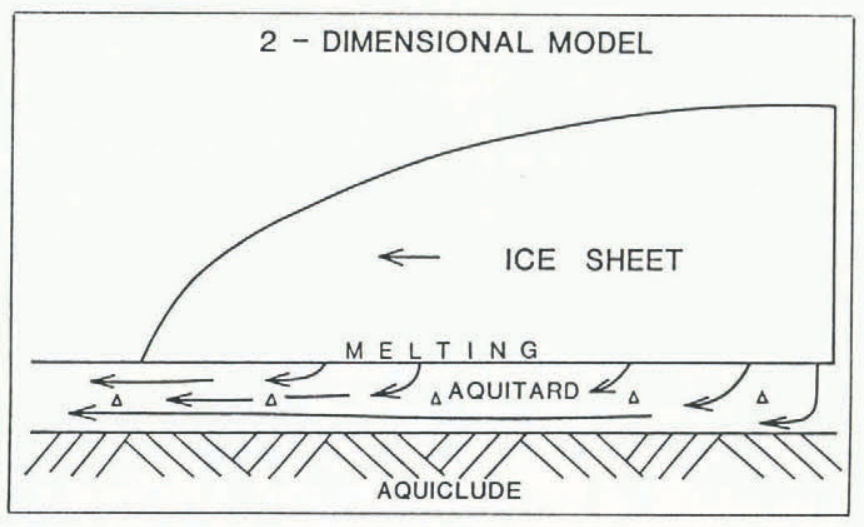

Fig. 6. Two-dimensional case. Aquiclude beneath till. There will be a vertical influx at the top of the till and a horizontal discharge through it. 
(1974) showed that the effective pressure at any point at the glacier sole would be:

$$
p^{\prime}=\frac{1}{P}\left[\frac{X_{1}^{2} m}{2 H T k}\left(\frac{x}{X_{1}}\right)^{2}+\left\{1-\left(\frac{x}{X_{1}}\right)^{2}\right\}^{\frac{1}{2}}+C\right]
$$

where $h$ is the ice-sheet thickness at the divide and $C$ is the sediment cohesion.

For typical values of till thickness, permeability and glacier melting rate, $p^{\prime}$ tends to zero when the glacier extent is no more than a few tens of kilometres in extent. This process is illustrated in Figure $7 \mathrm{a}$ for a glacier which progressively extends over a till surface. After extension to about $20 \mathrm{~km}$, the water-pressure head in the terminal zone equals the ice pressure, thus inducing instability in the terminal zone. Figure $8 \mathrm{~b}$ shows critical values of till thickness, permeability and flowline length which will lead to instability for a constant melting rate of $10^{-2} \mathrm{~m}$ year $^{-1}$ derived from Equations (24) and (27).

In view of the predominantly horizontal water flow in the two-dimensional case, $\partial \psi / \partial z$ will be zero and the vertical effective pressure gradient will be gravitational.

Assuming $10 \mathrm{~m}$ to be a typical till thickness, a till of low permeability, typical of those found in mountainous hard-rock regions, may be able to discharge all subglacial meltwater without the need for channels to develop. However, given the frequency with which surface drainage finds its way to the bed in such glaciers, unchannelled beds are likely to be rare. In this case, subglacial effective pressures will be as shown in Figure $8 c$. a)
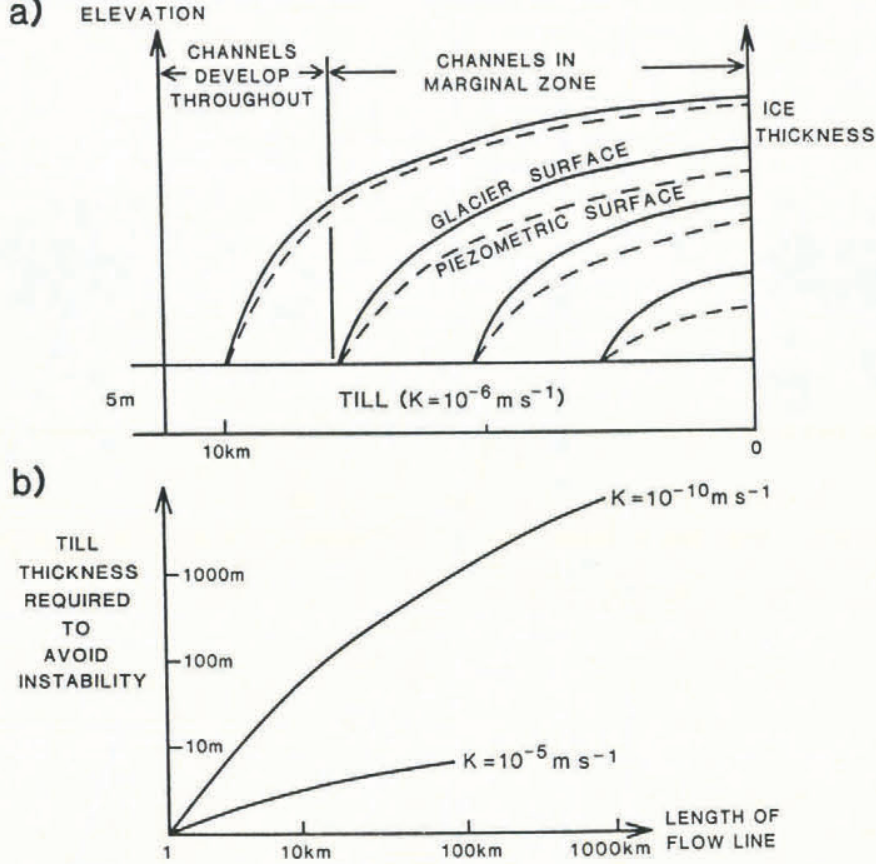

Fig. 7a-b. (a) Expansion of an ice sheet melting basally, over a till stratum of uniform thickness and permeability, which is in turn underlain by an aquiclude. It shows how the piezometric surface will increase until effective pressure tends to zero, and channels develop to avoid unstable deformation. (b) The till thickness required in the twodimensional case to discharge subglacial meltwater and avoid deformation. Beneath a large glacier, low-permeability tills are bound to deform; and thin, highpermeability tills will also tend to deform. The basal melting rate is as in (a).

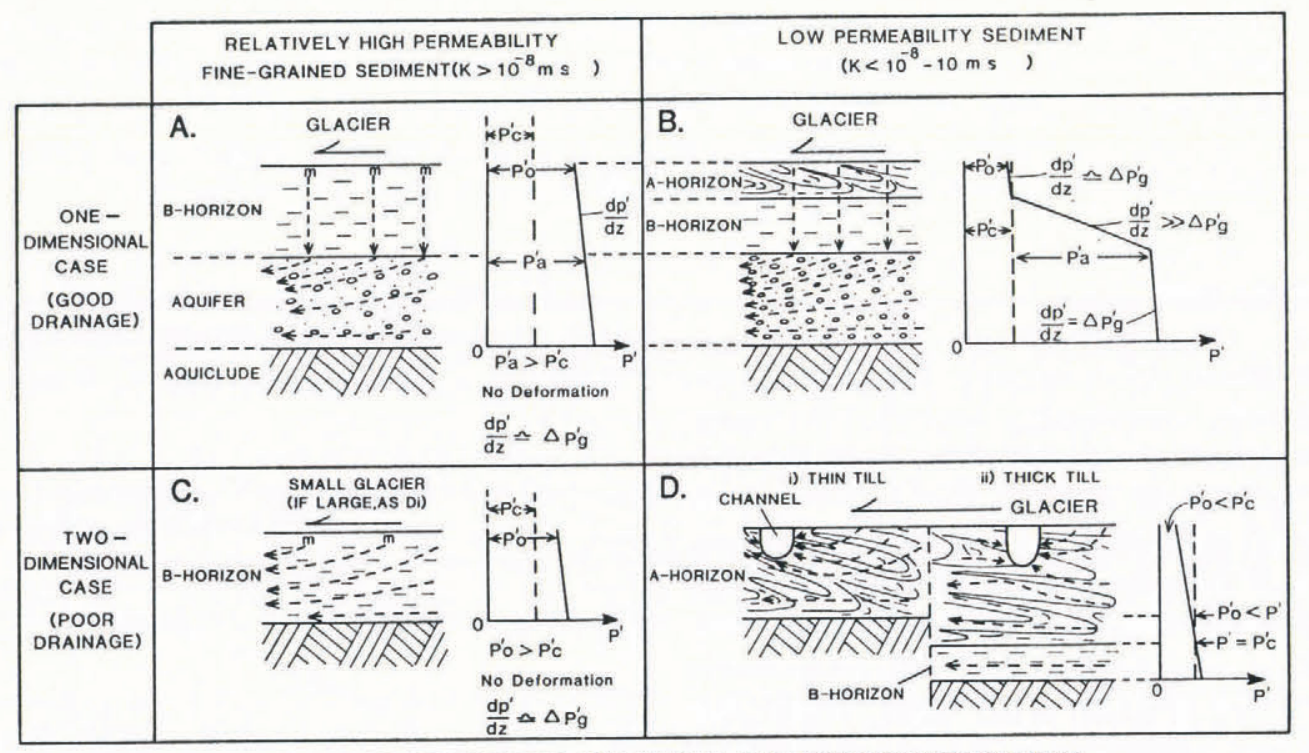

END MEMBER STATES FOR SUBGLACIAL SHEARING/CONSOLIDATION

Fig. 8. The effect of till permeability and sub-till drainage conditions on the occurrence of subglacial shear deformation and effective pressure gradients in the till. $p_{\mathrm{c}}{ }^{\prime}=$ effective pressure threshold for deformation, $p_{0}{ }^{\prime}=$ effective pressure at the glacier sole, $p_{\mathrm{a}}{ }^{\prime}=$ effective pressure at the base of the aquitard, $\partial p^{\prime} / \partial z=$ effective pressure gradient, $\left(\partial p^{\prime} / \partial z\right)_{\mathrm{g}}=$ vertical gradient of the gravitational component of effective pressure. A-D show end-member states. A. High till permeability and good drainage favour no deformation. B. Low till permeability and good drainage favour large $\partial p^{\prime} / \partial z$ and deformation in the upper part of the till. C. High till permeability and poor drainage may fail to induce deformation in a small glacier if the till can transmit a small water discharge with low $\partial p / \partial z$, but a large glacier will favour case $D i$. $D$. Low permeability and poor drainage will favour deformation of the till throughout (Di) or in all but a basal horizon if the till is very thick (Dii). $\partial p^{\prime} / \partial z$ is gravitational. 


\section{SUBGLACIAL DRAINAGE PATHWAYS: GROUND- WATER FLOW, CHANNEL FLOW AND SHEET FLOW}

We have considered above cases where meltwater is discharged by ground-water flow alone. What determines whether it takes this route or one of the other two?

If a glacier directly overlies an aquifer of high transmissibility so that all meltwater can be driven through it by a water potential gradient which ensures that the water pressure at the top of the aquifer is always significantly lower than the ice pressure, no water will build up at the glacier sole and no channels or water sheets will develop there. There are many such aquifers which have lain beneath Pleistocene ice sheets, capable of discharging all likely subglacial discharge fluxes (see below).

If, however, the aquifer is overlain by a till, or other sediment capping of low permeability, the potential gradient required to drive all the meltwater through the stratum (Equation (25)) may require a potential drop $(\Delta \psi)$ across the stratum which is larger than the ice pressure minus the aquifer pressure. This occurs when

$$
\frac{m \rho_{\mathrm{w}} g t}{k}>p_{\mathrm{i}}-\psi_{\mathrm{a}}
$$

As a consequence, water will build up on the surface of the till, whence it must be discharged by channel flow or sheet flow.

If, however,

$$
\frac{m \rho_{\mathrm{w}} g t}{k}<p_{\mathrm{i}}-\psi_{\mathrm{a}}
$$

all the meltwater will be discharged through the stratum, no channels or water sheets will develop at the glacierbed interface, and the effective pressure at the glacier sole will be as in Equation (26).

\section{TILL DEFORMATION AND ITS RELATION TO THE DRAINAGE PATHWAY}

The value of effective pressure at the glacier sole determines the shear resistance to glacier movement and is fundamental to many aspects of subglacial sedimentary processes and glacier dynamics.

We assume that there will be tight interlocking between basal ice and sediment grains so as to inhibit sliding at the glacier sole, and that shear deformation within the sediment occurs when the shear stress at the base of the glacier equals the yield strength of the sediment $(S)$. $S$ can be approximated by a failure criterion of the form:

$$
S=p^{\prime} \tan \phi+C
$$

where $\phi$ is the angle of internal friction and $C$ is cohesion.

A critical effective pressure $\left(p_{\mathrm{c}}{ }^{\prime}\right)$ can therefore be defined at which sediment deformation will occur:

$$
p_{\mathrm{c}}{ }^{\prime}=\frac{\tau_{\mathrm{b}}-C}{\tan \phi}
$$

where $\tau_{\mathrm{b}}$ is the shear stress at the base of the glacier.
The hydraulic transmissibility of low-permeability clay tills, typical of most soft-rock lowland regions, will be exceeded only a few kilometres down-glacier from the point of initiation of melting. This inevitably leads to deformation of the till and the formation of tunnels at the glacier-sediment interface to discharge excess water and prevent unstable deformation. Thus, in lowland regions glaciated by Pleistocene ice sheets, we expect most clay tills underlain by aquicludes to have been subject to a maximum effective pressure in the vicinity of the critical effective pressure for deformation $\left(p_{\mathrm{c}}{ }^{\prime}\right)$. Moreover, if we know values of pre-consolidation pressure and $\phi$ and $C$ for the till, the vertical effective pressure gradient through the till will simply be given by the submerged weight of the sediments.

The effective pressure at the glacier sole will largely be determined by the extent to which meltwater can drain away through the substratum. For a sediment bed beneath an ice sheet, where we expect only basally derived meltwater, channels will develop at the glacierbed interface only where the capacity for intergranular drainage is exceeded by the melt rate.

Figure 8 summarizes the different conditions which can exist at the bed. Figure $8 \mathrm{a}$ and $\mathrm{b}$ show the onedimensional case. In Figure $8 \mathrm{a}$, drainage through the aquifer is good and water pressure in the aquifer is low, giving a high effective pressure $\left(p_{0}^{\prime}\right)$. The till has a high permeability so that the potential drop across it is small, the effective pressure at the glacier sole is higher than $p_{0}{ }^{\prime}$ and no till deformation occurs. No channels develop. If the till permeability is low, the potential drop across it will be large, so that the effective pressure at some horizon in the till equals $p_{0}{ }^{\prime}$ (Fig. 8b). Above this level, deformation of the till will occur as a tectonic A horizon. The underlying, stable till is the B horizon.

Figure $8 \mathrm{c}$ and $\mathrm{d}$ show possible deformational conditions at the glacier bed for the two-dimensional case, where drainage must take place horizontally through the till stratum and will therefore be poor. Figure $8 \mathrm{c}$ shows a small glacier, where the horizontal water discharge will be small, and the till may be permeable enough to discharge meltwater without build-up of water at the glacier sole, so that $p_{0}{ }^{\prime}>p_{\mathrm{c}}{ }^{\prime}$. No deformation occurs. In most cases (Fig. 8d), however, drainage through the till will be insufficient to discharge the meltwater from the glacier-bed interface, and tunnels will develop so that $p_{0}$ tends to zero and the till deforms. Deformation will cease at the base of the A horizon. If we assume that deforming, dilatant till has a relatively high permeability so that $\partial \psi / \partial z \rightarrow 0$, the thickness of the $\mathrm{A}$ horizon $\left(t_{\mathrm{A}}\right)$ will be, from Equations (6) and (29),

$$
t_{\mathrm{A}}=\frac{\left(\frac{\tau_{\mathrm{b}}-C}{\tan \phi}\right)-p_{0}^{\prime}}{\left(\frac{\partial p^{\prime}}{\partial z}\right)_{\mathrm{g}}}
$$

If $p_{0}{ }^{\prime}$ is zero and we take the following range of values, $\tau_{\mathrm{b}}=50-100 \mathrm{kPa}, C=0-25 \mathrm{kPa}, \phi=12-30^{\circ}$ and $\left(\partial p^{\prime} / \partial z\right)_{\mathrm{g}}=10 \mathrm{kPa} \mathrm{m}^{-1}, t_{\mathrm{A}}$ will vary from 4 to $47 \mathrm{~m}$. In most cases, therefore, we expect the whole till to deform, although if the till is very thick, there may be an undeformed lower horizon. 

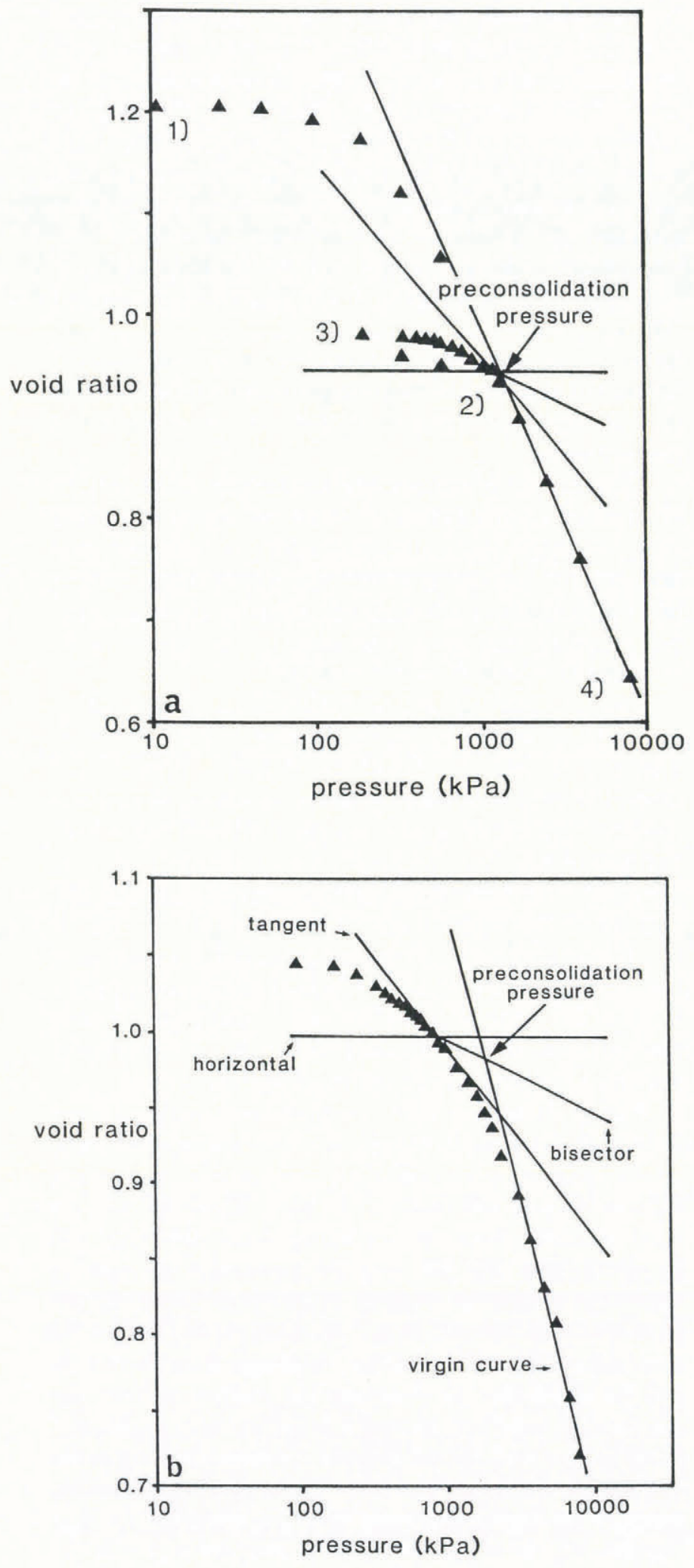

Fig. 9a-b. Examples of pre-consolidation determination. (a) Testing the method. Remoulded sample loaded from (1) to (2) and then unloaded to (3). Unloading produces a smaller elastic response. Further loading to (4) shows strong curvature near (2), the maximum load to which the sediment had previously been consolidated. Casagrande's graphical reconstruction on curve (3)-(4) locates the preconsolidation at (2) accurately. Pre-consolidated clays are naturally in the state shown by an extension of (3). (b) Consolidation test on a Peelo Clay sample showing determination of the pre-consolidation pressure using Casagrande's graphical reconstruction.

\section{PRE-CONSOLIDATION AND THE DETERMIN- ATION OF PAST MAXIMUM EFFECTIVE PRES- SURES IN SEDIMENTS}

An opportunity to test the theoretical concepts developed above and examine evidence of subglacial consolidation and ground-water flux can be derived from Casagrande's (1936) recognition that clay-rich sediments preserve a record of their history of loading. A newly deposited clayrich sediment which is subjected to an increase in overburden pressure will consolidate by pore-water expulsion. If the rate of loading is slow enough to permit equilibration of the grain skeleton, the porosity of the sediment will be related to effective pressure by Equation (16).

If the load is removed from the sediment, it does not rebound elastically to its former state but preserves in its structure some record of the former load. Such a sediment is said to be overconsolidated. Figure 9a shows an example of the change in void ratio of a completely remoulded sample of Peelo Clay from Holland which has been loaded to $1200 \mathrm{kPa}$ and then completely unloaded. The contrast between the overconsolidated sample after unloading to point 3 , and the normally consolidated sample at a similar pressure on line $1-2$ is shown by a void-ratio difference of about 0.2 . This reflects permanent, plastic re-organization of the sediment skeleton during the initial loading, thus reducing the elastic response during unloading.

Casagrande (1936) used the rapid change in the rate of volume change near the point of maximum previous loading to suggest a graphical method whereby this load, the degree of sediment overconsolidation, may be determined (see also MacDonald and Sauer, 1970; Khera and Schulz, 1984; Sauer and Christiansen, 1988). It is shown in Figure 9b. The method was tested for the Peelo Clay sample shown in Figure 9a by reloading it to $10000 \mathrm{kPa}$, unloading and then determining the pre-consolidation load graphically (Fig. 9b). This agreed well with the actual pre-consolidation load applied during the first experiment.

\section{APPLICATION AND HYPOTHESIS TESTING 1 - THE ONE-DIMENSIONAL CASE: THE PEELO GLAYS OF HOLLAND}

The Peelo Clays of the northern Netherlands (Fig. 10), and their equivalents in northern Germany, were laid down in lakes in deep basins during the retreat of the Elsterian ice sheet. They overlie a thick aquifer composed of earlier Pleistocene sand and gravel formations (Urk, Enschede and Harderwijk Formations) which in turn overlie the relatively impermeable lowermost Pleistocene and uppermost Tertiary formations of Tegelen, Maassluis and Oosterhout (Fig. 11). During the succeeding Saalian glaciation, this sequence was over-run by an ice sheet extending to the northern bank of the River Rhine, which deposited a till and associated sediments (the Drenthe Formation) over the Peelo Clays (Figs 10 and 11).

The Peelo Clays are overconsolidated, presumably as a consequence of glacier loading and, because of their 


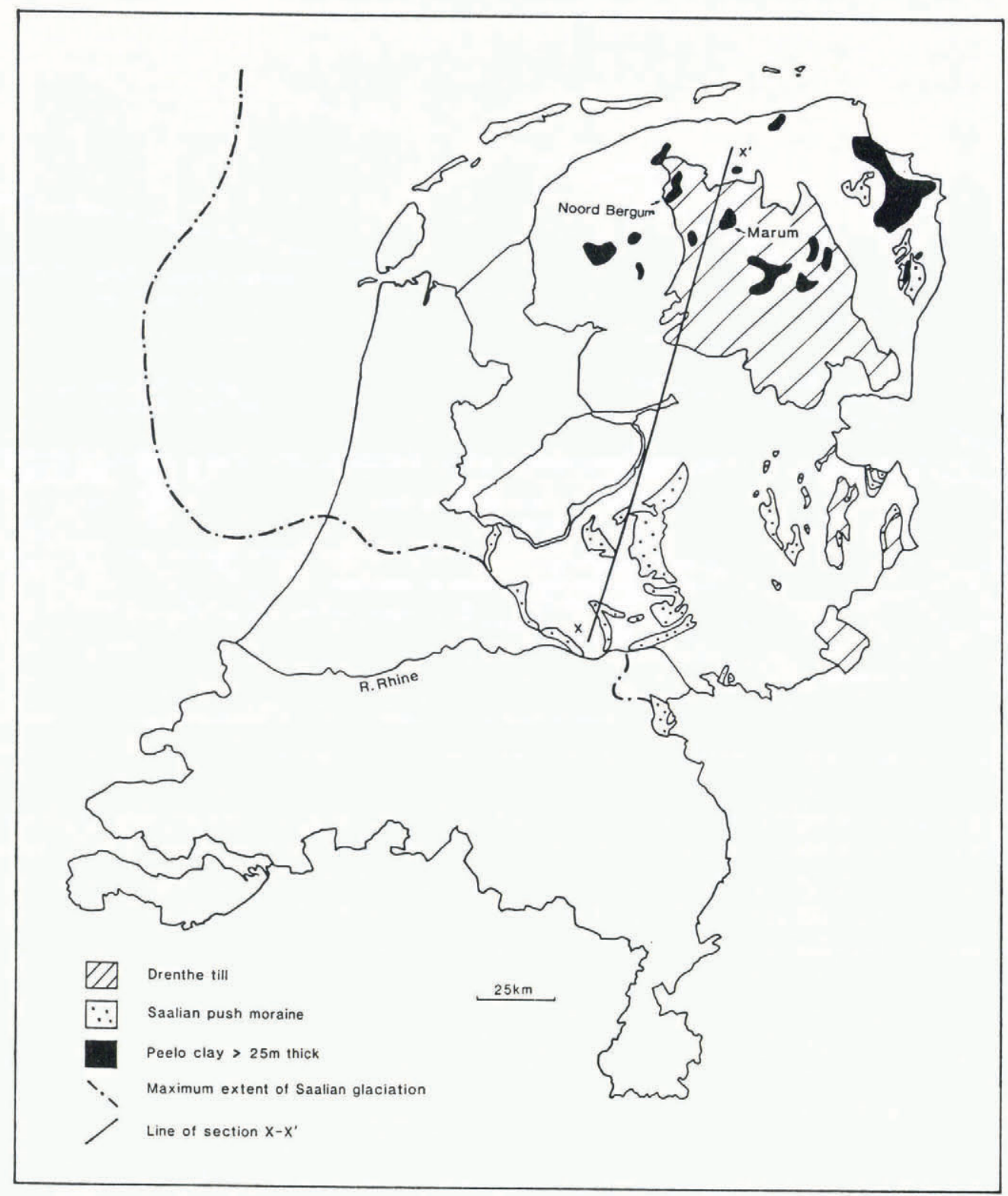

Fig. 10. Map showing the extent of Saalian glaciation in The Netherlands and adjacent North Sea, the terminal Saalian push moraines and the Peelo Clay deposits. The Marum and Noord Bergum sites and the location of the transect in Figure 11 are shown.

fine-grained and homogeneous nature, are an ideal medium to preserve a record of pre-consolidation. The tests, exemplified in Figure 9a and b, confirmed this.

Although the Peelo Clays are not tills, there is no reason why they should not have preserved the overconsolidation characteristics suggested in early sections. They are underlain by a thick aquifer with a large hydraulic transmissibility, and we would thus expect subglacial meltwater to flow vertically through them as in the one-dimensional case. Their vertical permeability is low $\left(<10^{-10} \mathrm{~m} \mathrm{~s}^{-1}\right)$ and thus they should have experienced a high subglacial vertical potential gradient giving an effective pressure gradient much larger than the gravitational gradient, as shown in Figure 5a.

Samples were provided by F. Schokking of the Dutch Geological Survey from a boring at Noord Bergum (Fig. 12). The Peelo Clay basin was overlain by the glacial Drenthe Formation and underlain by a sand and gravel samples were taken. They were sealed carefully and waxed to prevent moisture loss. Conventional consolidation tests described by British Standard BS 1377 (1975), were taken using pressures of up to $10000 \mathrm{kPa}$.

Values of pre-consolidation load for a series of samples selected from massive clays of similar grain-size composition from Noord Bergum are plotted in Figure 13a and analogous clays from a nearby borehole at Marum (Schokking, 1990) are plotted in Figure 13b. Below $28 \mathrm{~m}$ at Marum, the Peelo Clays became significantly more siltand sand-rich. Measurements of pre-consolidation below this level fall below a linear regression through data on the overlying clays. It is suggested that they have responded differently to loading, and have therefore been excluded from the analysis. Linear regression on the clay-rich horizons at Noord Bergum and Marum give aquifer. Relatively massive clays (clay content $>60-70 \%$ ) occurred between 45 and $80 \mathrm{~m}$, and it was from here that 


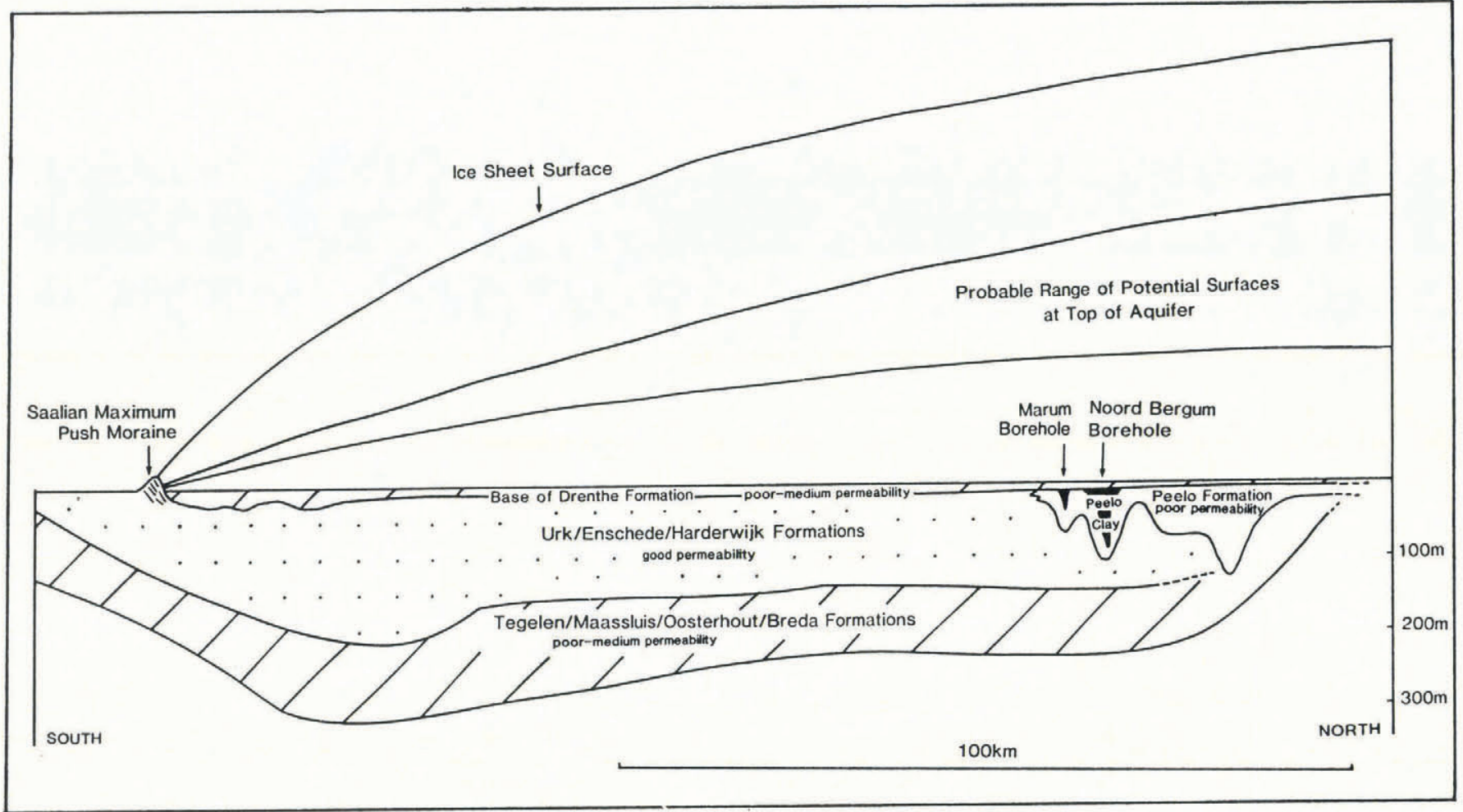

Fig. 11. Schematic section across The Netherlands (see Figure 10 for location) showing the principal aquifer overlain by the Peelo Clay basins of Marum and Noord Bergum, and the Saalian tills (Drenthe Formation). The Saalian ice-sheet surface at its maximum is inferred from the measurements on Peelo Clay samples from Marum and Noord Bergum fitted to a typical ice-sheet profile (Bodvarsson, 1955; Vialov, 1958). The calculated range of probable pressure gradients in the top of the aquifer is also shown.

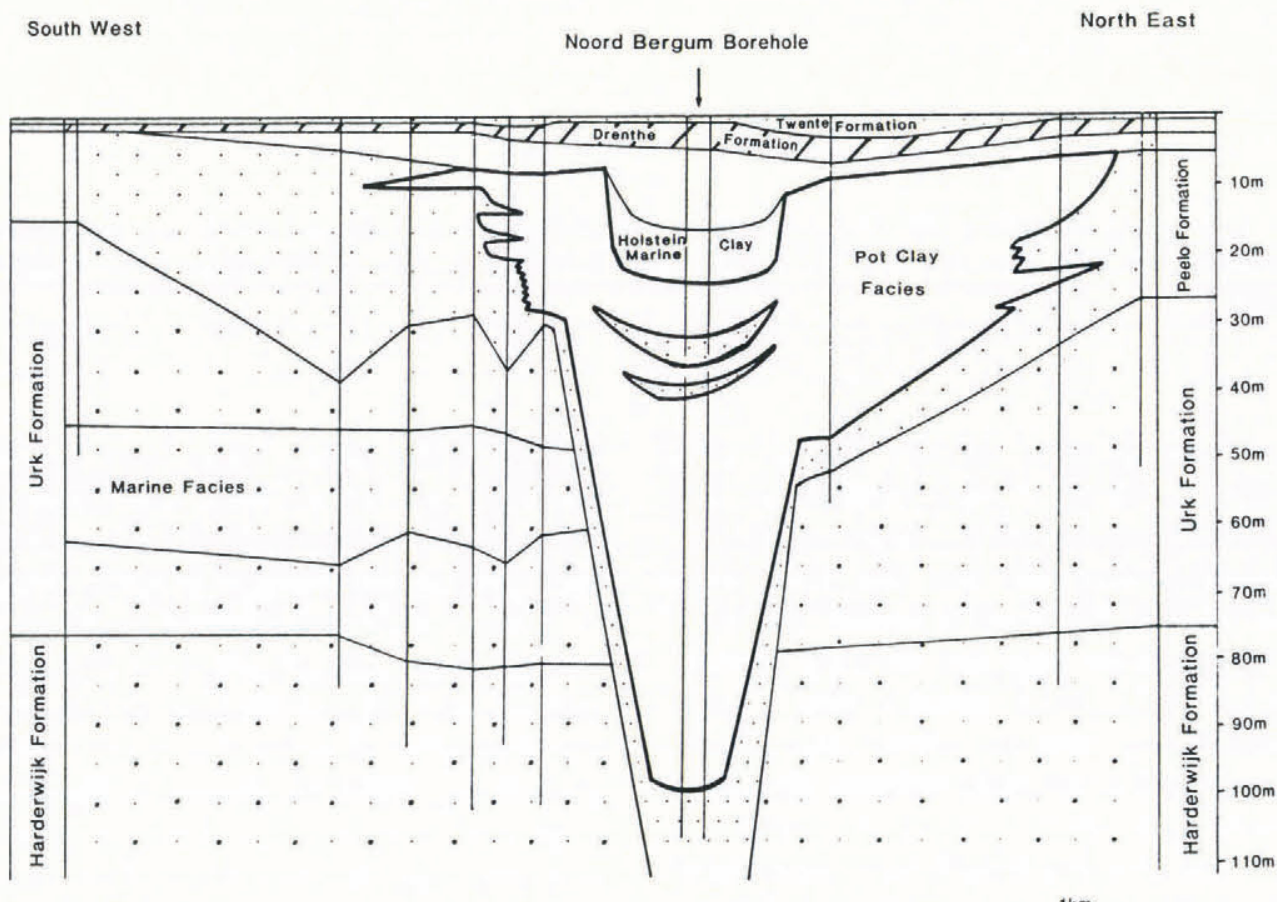

True Scale Section Across The Noord Bergum Basin

Fig. 12. Section across the Noord Bergum Peelo Clay basin. 
approximate values of vertical effective pressure gradient of:

Noord Bergum: $\frac{\partial p^{\prime}}{\partial z} \approx 111 \mathrm{kPa} \mathrm{m}^{-1} ;$

$$
\text { Marum: } \quad \frac{\partial p^{\prime}}{\partial z} \approx 68 \mathrm{kPa} \mathrm{m}^{-1}
$$

Measured values of void ratios at these effective pressures give a gravitational gradient during the period of maximum loading of:

Noord Bergum: $\left(\frac{\partial p^{\prime}}{\partial z}\right)_{\mathrm{g}}=11 \mathrm{kPa} \mathrm{m}^{-1}$;

Marum: $\quad\left(\frac{\partial p^{\prime}}{\partial z}\right)_{\mathrm{g}}=10 \mathrm{kPa} \mathrm{m}^{-1}$.

From Equation (11)

Noord Bergum: $\frac{\partial \psi}{\partial z}=\frac{\partial p_{\mathrm{g}}{ }^{\prime}}{\partial z}-\frac{\partial p^{\prime}}{\partial z}=-100 \mathrm{kPa} \mathrm{m}^{-1}$;

Marum: $\quad \frac{\partial \psi}{\partial z}=\frac{\partial p_{\mathrm{g}}}{\partial z}-\frac{\partial p^{\prime}}{\partial z}=-58 \mathrm{kPa} \mathrm{m}^{-1}$.
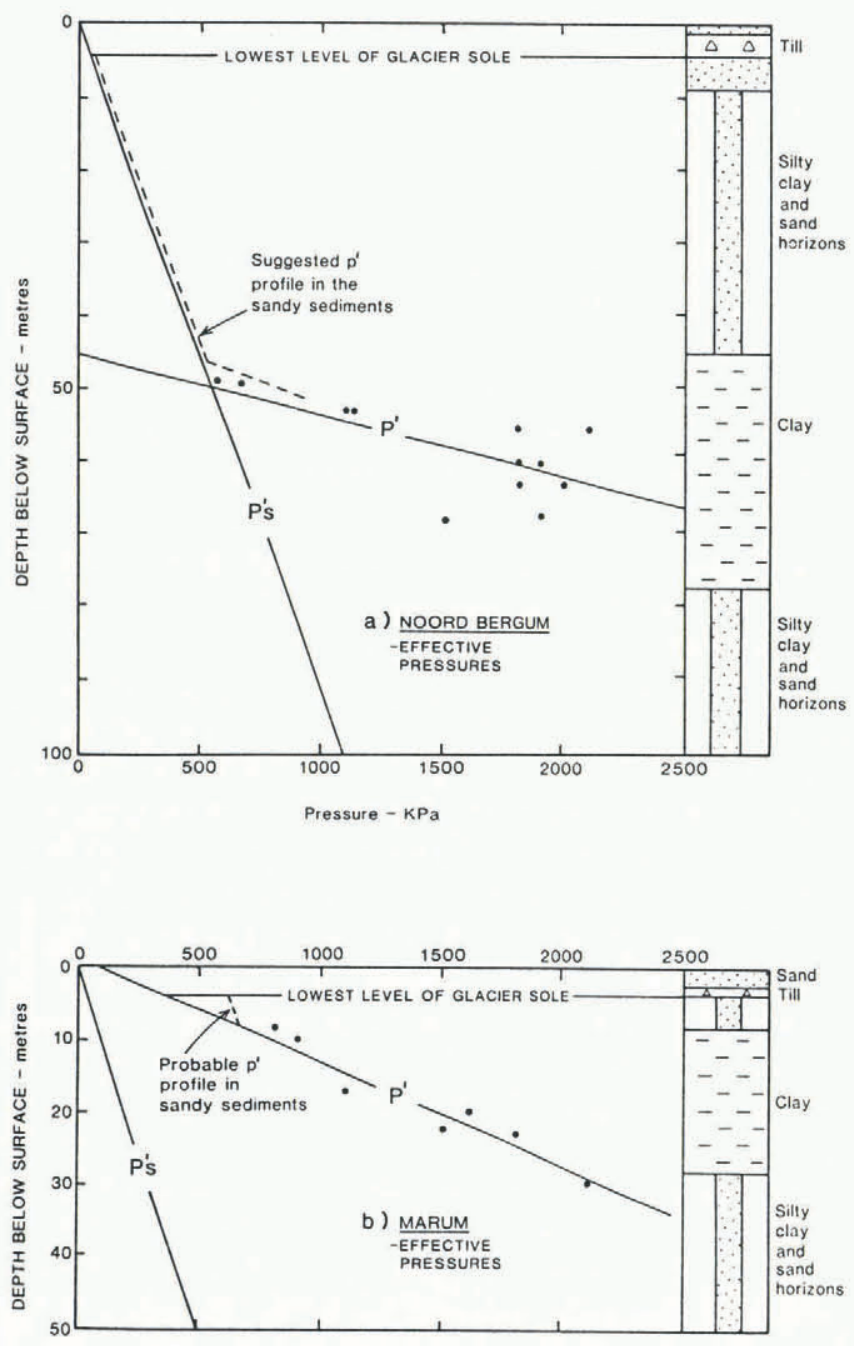

Fig. 13a-b. Stratigraphy in the Noord Bergum (a) and Marum (b) boreholes and pre-consolidation pressures in the Peelo Clays.
We assume that this was achieved during the phase of greatest ice thickness over the sites and that effective pressure gradients reflect the potential gradients required to drive meltwater through the clays. Given these values of $\partial \psi / \partial z$ and values of permeability derived from Equation (17) (determined by the consolidation test), we use Equation (25) to derive the basal melting rate

$$
\left(m=-k\left(\frac{\partial \psi}{\partial z}\right) \frac{1}{\rho_{\mathrm{w}} g}\right)
$$

Noord Bergum: $m=3 \mathrm{~mm}$ year $^{-1}$;

Marum: $\quad m=2 \mathrm{~mm}_{\text {year }}{ }^{-1}$.

This lies within the relatively narrow range of melting rates typical of non-surging glaciers. We are impressed by the inter-site agreement and the similarity between expected and inferred values, and regard it as a nontrivial test of the theory.

Above $-45 \mathrm{~m}$ at Noord Bergum (Fig. 13a), the character of the succession changes. It contains thick sand units interdigitating with fine-grained units containing abundant sandy and silty horizons. We have not measured vertical permeability in these upper beds, but believe it to be sufficiently high to have permitted vertical drainage of glacial meltwater without requiring a significant potential gradient. Thus, we suggest that above $-45 \mathrm{~m}$, the effective pressure gradient in the Peelo Formation was as shown in Figure 13a. The Saalian glacier is believed to have overridden the sequence at $-5 \mathrm{~m}$, and thus, the effective pressure at the glacier sole was approximately $50 \mathrm{kPa}$.

Similarly, at Marum, sandy units occur above $-8.5 \mathrm{~m}$. If we assume a gravitational pre-consolidation gradient between this depth and the top of the clays, the effective pressure at the base of the till at the glacial maximum would have been $600 \mathrm{kPa}$.

Measured and calculated values of important parameters from Noord Bergum are shown in Table 1, as are results from a nearby borehole in Peelo Clays at Marum calculated from measurements made by Schokking (1990). These latter show similar results and have also been drawn up in Figure 13b.

\section{Large-scale ground-water flow beneath the Saalian ice sheet in Holland and calculation of ice thick- ness}

In the case of Marum, we can be reasonably confident that $p_{0}{ }^{\prime}$ was much greater than zero, suggesting that all the basal meltwater was discharged through the Peelo Clays. At Noord Bergum, however, the data do not permit such an unequivocal conclusion. $p_{0}^{\prime}$ may have been zero, permitting water to build up at the glacier-bed interface and the discharge of water in channels or by sheet flow. Thus, the value of $m$ calculated at Noord Bergum may not be the melting rate, but merely that part of the meltwater discharged through the Peelo Clays. Nonetheless, given the similar values of $\partial p^{\prime} / \partial z$ at both sites, we suggest that the value of $p_{0}{ }^{\prime}$ at Noord Bergum may have been significantly greater than zero and that all, or most, meltwater was discharged through the clays. 
Table 1. Measured geotechnical characteristics at Noord Bergum and Marum and inferred ground-water and glacier characteristics

\begin{tabular}{|c|c|c|c|c|c|c|c|c|c|}
\hline \multicolumn{3}{|c|}{ Measured } & \multicolumn{7}{|c|}{ Inferred } \\
\hline $\begin{array}{l}\text { Vertical } \\
\text { effective } \\
\text { pressure } \\
\text { gradient } \\
\text { in clay }\end{array}$ & $\begin{array}{l}\text { Gravitational } \\
\text { effective } \\
\text { pressure } \\
\text { gradient }\end{array}$ & $\begin{array}{l}\text { Perm- } \\
\text { eability }\end{array}$ & $\begin{array}{l}\text { Potential } \\
\text { gradient }\end{array}$ & $\begin{array}{l}\text { Potential } \\
\text { drop across } \\
\text { the clay }\end{array}$ & $\begin{array}{l}\text { Aquifer } \\
\text { potential }\end{array}$ & $\begin{array}{c}\text { Effective } \\
\text { pressure at } \\
\text { glacier sole }\end{array}$ & $\begin{array}{c}\text { Melting } \\
\text { rate }\end{array}$ & $\begin{array}{c}\text { Ice } \\
\text { pressure th }\end{array}$ & $\begin{array}{c}\text { Ice } \\
\text { thickness }\end{array}$ \\
\hline$\frac{\partial p^{\prime}}{\partial z}$ & $\frac{\partial p_{\mathrm{s}}}{\partial z}$ & $k$ & $\frac{\partial \psi}{\partial z}$ & $\Delta \psi$ & $\psi_{\mathrm{a}}$ & $p_{0}^{\prime}$ & $m$ & $p_{\mathrm{i}}$ & \\
\hline $\mathrm{kPa} \mathrm{m}^{-1}$ & $\mathrm{kPa} \mathrm{m}^{-1}$ & $\mathrm{~ms}^{-1}$ & $\mathrm{kPa} \mathrm{m}^{-1}$ & $\mathrm{kPa}$ & $\mathrm{kPa}$ & $\mathrm{kPa}$ & nm year ${ }^{-1}$ & $\mathrm{kPa}$ & $\mathrm{m}$ \\
\hline \multicolumn{10}{|c|}{ Noord Bergum } \\
\hline 111 & 11 & $10^{-11}$ & -100 & 2500 & $1600-3250$ & 50 & 3 & $4300-5950$ & $478-661$ \\
\hline \multicolumn{10}{|l|}{ Marum } \\
\hline 68.3 & 10 & $10^{-11}$ & -58 & 1300 & $1600-3250$ & 630 & 2 & $3530-5180$ & $392-575$ \\
\hline & & & & \multicolumn{3}{|c|}{$m=\frac{-k}{\rho_{\mathrm{g}}} \cdot \frac{\partial \psi}{\partial z}$} & \multicolumn{3}{|c|}{$p_{\mathrm{i}}=\psi_{\mathrm{a}}+\Delta \psi+p_{0}^{\prime}$} \\
\hline
\end{tabular}

In order to determine the thickness of ice at Noord Bergum and Marum during the phase of maximum ice extent (assumed to be the period of maximum loading) from Equation (27) $\left(p_{\mathrm{i}}=\psi_{\mathrm{a}}+\Delta \psi_{\mathrm{c}}+p_{0}{ }^{\prime}\right)$, we need to know $\psi_{\mathrm{a}}$, the potential at the top of the aquifer beneath the Peelo Clays (see also Fig. 4c).

An estimate of the magnitude of $\Delta \psi_{\mathrm{a}}$ can however be made if we make several assumptions:

(a) The melting rates calculated for Noord Bergum and Marum of about 2-3 mm year $^{-1}$ were typical of the whole zone of subglacial melting beneath the Saalian ice sheet.

(b) Although we have no direct evidence of the extent of basal melting beneath the Saalian ice sheet, we assume a pattern of subglacial melting for a midlatitude ice sheet similar to that calculated by Hindmarsh and others (1989). These calculations suggest a fairly stable condition in which, behind a narrow marginal frozen zone, temperatures are at the melting point for a distance in excess of $300-400 \mathrm{~km}$ from the ice-sheet margin in an ice sheet the size of the European Saalian.

(c) That the meltwater was primarily discharged within the sandy aquifer provided by the Urk, Enschede and Harderwijk Formations (Fig. 11), and that their horizontal permeability was similar to their modern average of $10^{-4} \mathrm{~m} \mathrm{~s}^{-1}$. This aquifer extends into Germany, and could have acted as the major medium of subglacial water discharge for as much as $800 \mathrm{~km}$ from the Saalian ice-sheet margin.

(d) That the permeability of sandy sediments is relatively insensitive to changes of pressure at the low effective pressures being considered here.

We then use a simple formulation for ground-water flow in a two-dimensional aquifer of given thickness, permeability and recharge (Jacob, 1940) to calculate the potential gradient at the top of the aquifer as shown in Figure 11. This gives a value for $\psi_{\mathrm{a}}$ at Noord Bergum and Marum. The inner zone of the ice sheet and the terminal zone, where the glacier sole lies below the melting point, are assumed to be zones of zero recharge to the aquifer. Beneath the inner frozen zone, there will be no groundwater discharge and a constant ground-water head, whilst beneath the outer frozen zone there will be a constant ground-water discharge and the potential gradient will be constant. The results of this computation are shown in Figure 14 for a melting zone of widths 400 and $800 \mathrm{~km}$.

The calculated range of values of $\psi_{\mathrm{a}}$ for the area of Noord Bergum/Marum for melting rates of $3 \mathrm{~mm}_{\text {year }}{ }^{-1}$ and melting-zone widths of 400 and $800 \mathrm{~km}$ width, are 1600 and $3250 \mathrm{kPa}$, respectively. Using Equation (27), $\left(p_{\mathrm{i}}=\psi_{\mathrm{a}}+\Delta \psi_{\mathrm{c}}+p_{0}{ }^{\prime}\right)$ and the values of $\psi_{\mathrm{a}}, \Delta \psi_{\mathrm{c}}$ and $p_{0}{ }^{\prime}$ shown in Table 1 , ice pressures $\left(p_{\mathrm{i}}\right)$ for Noord Bergum and Marum are calculated as 4300-5950 and 3530$5180 \mathrm{kPa}$, respectively, equivalent to ice thicknesses of $478-661$ and $392-575 \mathrm{~m}$, respectively. 


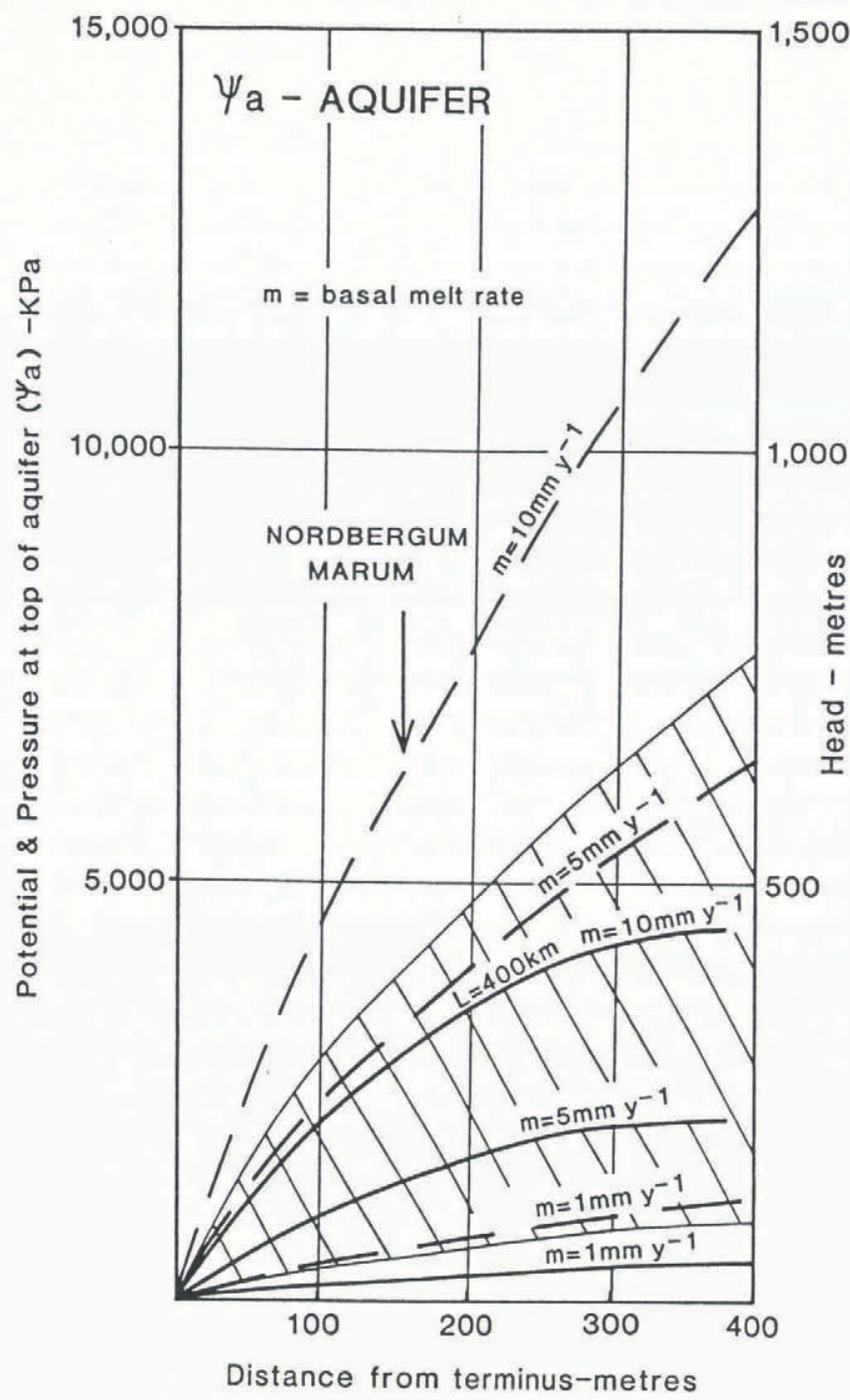

Fig. 14. Reconstructed subglacial piezometric surfaces for the top of The Netherlands aquifer for a melting zone of $400 \mathrm{~km}$ width (solid lines) and one of $800 \mathrm{~km}$ width (dashed lines) and for a range of melting rates. The line of section is that shown in Figures 10 and 11. The shaded area shows the most likely range of surfaces. The position of the Noord Bergum and Marum boreholes are projected on to the transect.

We have assumed a mean value of ice thickness of $525 \mathrm{~m}$ in the Noord Bergum/Marum region and used Equation (28) to compute a longitudinal ice-sheet profile, assuming that the ice-sheet span $(L)$ is approximately $1000 \mathrm{~km}$ (Fig. 11). This yields an average basal shear stress in the area between Noord Bergum/Marum and the Saalian ice-sheet terminus in the region of $10 \mathrm{kPa}$. It is significantly below values of shear stress typical of modern glaciers resting on rock beds, which are normally of the order of $60-120 \mathrm{kPa}$. The low value of reconstructed shear stress may reflect pervasive subglacial sediment deformation as suggested by Boulton and Jones (1979).

We note the relative absence of tunnel valleys in The Netherlands compared with the adjacent North Sea and suggest that a high-transmissibility aquifer will inhibit subglacial channel formation and the production of tunnel valleys by the mechanism suggested by Boulton and Hindmarsh (1987).

\section{APPLICATION AND TESTING 2 - TILLS OF RELATIVELY HIGH PERMEABILITY: THE DEV- ENSIAN OF EASTERN ENGLAND}

Our theory suggests that subglacial sediment with a permeability of less than $10^{-8}-10^{-10} \mathrm{~m} \mathrm{~s}^{-1}$ should show a vertical pre-consolidation gradient which is approximately gravitational, much less than that of the Peelo Clays. On the coast of eastern England are exposed a series of tills with permeabilities in the range $10^{-5}-10^{-7}$ $\mathrm{m} \mathrm{s}^{-1}$ and which should, according to our theory (Figs 3, 5 and $8 \mathrm{~b})$, show vertical gradients of pre-consolidation pressure which are approximately gravitational.

The last, Devensian, ice sheet flowed down the east coast of England and terminated in northern Norfolk (Fig. 15). It laid down a thick sequence of tills along the coast of Yorkshire and Lincolnshire which are typically $10-20 \mathrm{~m}$ in thickness (Catt and Penny, 1966). At Dimlington, just north of the River Humber, a thick till sequence is underlain by a moss bed ${ }^{14} \mathrm{C}$-dated at $18240 \pm 250$ and $18505 \pm 400$ years BP (Penny and others, 1969). The oldest date from organic material overlying the tills was obtained from Roos Bog (Catt, 1977), $10 \mathrm{~km}$ north of Dimlington, and is $13045 \pm$ 270 years BP. The tills above the moss bed are therefore of late Devensian age.

However, it is not clear whether the underlying rocks would have permitted free basal drainge of the tills, as in the one-dimensional case, or have prevented vertical drainage, as in the two-dimensional case. The glacial drift sequence down the coast is underlain by the Chalk

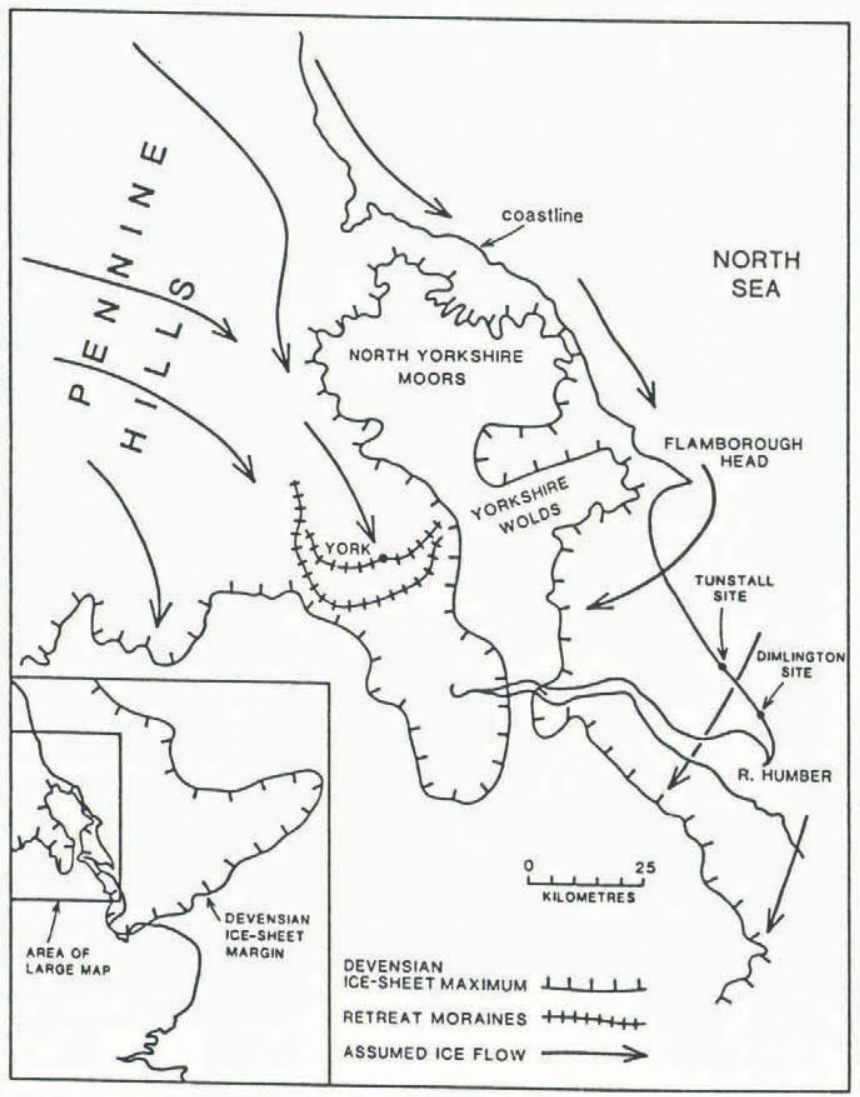

Fig. 15. Map showing the extent of the late Devensian ice sheet down the east coast of England showing localities referred to in the text. 
(Cretaceous) and then by a clay-dominated Jurassic sequence. The edge of the Chalk outcrop to the west roughly coincides with the reconstructed margin of the Devensian ice sheet, but trends directly away from the margin in the south. The Chalk is generally a good aquifer in the many areas where it is highly fractured. Elsewhere, it may be relatively impermeable.

If, as has been suggested, the ice-sheet margin had a frozen substratum (Boulton and others, 1977), and because of the rapid advance of the Devensian ice sheet over permafrost terrain, it is possible that the thin Chalk wedge at the western margin of the east coast lobe may have been hydrologically sealed by permafrost. It is thus not clear whether or not the Chalk would have acted as in the one-dimensional case, as an efficient drain at the base of the ice sheet in the way we suggest for the Saalian ice sheet in The Netherlands. If the Chalk acted as an efficient drain, it would dissipate pore-water pressures in the till, which would therefore show high pre-consolidation values as in Figure 8a. If, though permeable itself, water were unable to escape from the Chalk because of frozen discharge points, subglacial meltwater would not be efficiently removed from the system, pore-water pressures would be high, the till would not be highly consoldiated, and the system would behave as shown in Figure 8d, showing relatively low pre-consolidation values.

We have therefore sought, through a series of preconsolidation tests, both to test the theory by establishing whether the vertical pre-consolidation gradient is indeed gravitational and to establish the nature of part of the subglacial hydrological system, whether it is two- or onedimensional (Figs 4 and 6).

Two sites were chosen, one near the summit of Dimlington Cliff, where the late Devension till sequence is up to $30 \mathrm{~m}$ in thicknesss (Figs 15 and 16a) and at
Tunstall where $18 \mathrm{~m}$ of till are exposed. The Devensian till sequence has been subdivided by Catt and Penny (1966) into two, with an upper, Withernsea Till, overlying a lower, Skipsea Till. A series of simple index tests (granulometry, liquid and plastic limits) show values similar to those determined by Foster (1983) in more detailed analyses of the Withernsea and Skipsea Tills in a test borehole at Cowden, $30 \mathrm{~km}$ north of Dimlington.

\section{Dimlington site}

Samples were taken by excavating $2-3 \mathrm{~m}$ in from the cliff face at fresh natural exposures. Large (approx. $0.01 \mathrm{~m}^{3}$ ) samples were taken and wax-coated in the field. In the laboratory, as many consolidation cell sub-samples as could be obtained without disturbance were taken from the field samples. Consolidation tests were then undertaken on 13 samples; three from locality A, two from B, four from C, three from D and one from from locality $\mathrm{E}$ (Fig. 16a). A first series of tests was undertaken by loading up to $10000 \mathrm{kPa}$ to determine the form of the consolidation curve and a further series involved loading to $5000 \mathrm{kPa}$.

Pre-consolidation values were then determined using Casagrande's graphical method and are shown plotted in Figure $16 \mathrm{~b}$. In general, values are very much smaller than determined for the Peelo Clays. They also fail to show the large vertical pre-consolidation gradients found in the Peelo Clays. Gradients approximately conform to the modern gravitational gradient of effective pressure, suggesting that the permeability of the tills was sufficiently large to inhibit any large potential pressure gradient.

There appears to be a slight divergence between the gravitational effective pressure gradient and the linear regression through pre-consolidation values of about
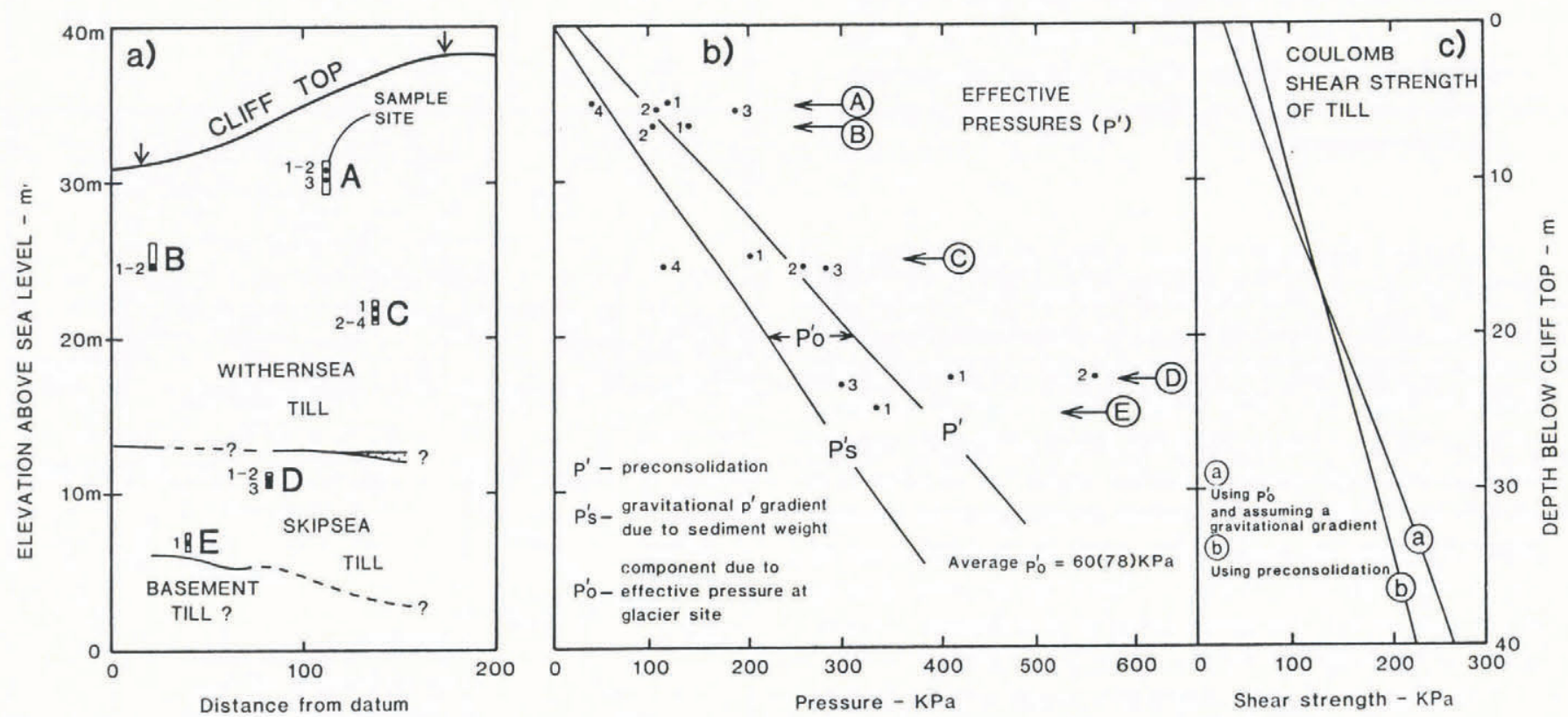

Fig. 16a-b. The Dimlington Cliff locality. (a) Location of sampling sites. Sample numbers are shown at each site. (b) Pre-consolidation results for the samples located in (a). The vertical pre-consolidation gradient in this till of relatively high permeability is approximately gravitational. The shear strength is determined using $\phi=24^{\circ}, C^{\prime}=18 \mathrm{kPa}$. 
$\partial \psi / \partial z=1 \mathrm{kPa} \mathrm{m}^{-1}$. This might reflect a basal melting rate of $30 \mathrm{~mm}$ year $^{-1}$ (Equation (18)), although we are sceptical that the divergence is not due to chance. If the gradient is predominantly gravitational, the average difference between the effective pressure due to the water-saturated sediment alone and the pre-consolidation values will give $p_{0}{ }^{\prime}=60 \mathrm{kPa}$, the effective pressure at the glacier sole. The value of $p_{0}{ }^{\prime}$ extrapolated by linear regression in Figure 16 is $22.5 \mathrm{kPa}$.

Values of Coulomb strength parameters (Equation (18)) $\phi$ and $C$ were determined by triaxial testing of $8 \mathrm{~cm} \times 10 \mathrm{~cm}$ diameter samples and yielded results in the range $\phi=26.6_{-4}^{\circ+2}$ and $C=24 \mathrm{kPa}_{-13}^{+11}$ (samples which proved to have clasts larger than $1.5 \mathrm{~cm}$ in diameter were rejected). These are so close to the values obtained by Foster (1983), in a much more detailed study of local tills, that we have used his mean values of $\phi=24^{\circ}$ and $C=18 \mathrm{kPa}$. We believe that large-scale joints in the tills derive from a later stage in their history.

If we assume that $p_{0}{ }^{\prime}=60 \mathrm{kPa}$ and that $\partial p^{\prime} / \partial z$ is gravitational, the shear strength of the tills immediately beneath the glacier sole would be $45 \mathrm{kPa}$, and the shearstrength profile would be that shown by curve (a) in Figure 16b.

If the regression line determined for values of preconsolidation in Figure $16 \mathrm{~b}$ accurately reflects $\partial p^{\prime} / \partial z$, the effective pressure at the glacier sole $p_{0}{ }^{\prime}$ would be $22.5 \mathrm{kPa}$, the shear strength immediately beneath the glacier sole would be $28 \mathrm{kPa}$ and the shear-strength profile would be as shown by curve (b) in Figure 16b.

We thus conclude that the maximum shear stress at the base of the late Devensian glacier in Holderness was between about 18 and $45 \mathrm{kPa}$, compared with typical shear stresses at the bases of modern glaciers resting on rigid beds, which lie within the range $60-120 \mathrm{kPa}$. We suggest that the significantly lower maximum basal shear stresses inferred for the Devensian ice sheet in eastern England reflected deformation of subglacial tills as a consequence of high pore-water pressures.

We conclude therefore:

(a) That the low vertical effective pressure gradient in the till agrees with the predictions of the theory that high-permeability tills will show a gravitational effective pressure gradient (Figs 3 and 5).

(b) That the low effective pressures, produced by high water pressures, must reflect poor drainage through the underlying Chalk, possibly because of freezing of the Chalk outlet.

(c) That deformation of soft subglacial sediment permitted the glacier to flow under low shear stresses and with a low gradient.

\section{Tunstall site}

A thinner sequence, though otherwise similar to that at Dimlington, was sampled at Tunstall (TA 307322) (Madgett and Catt, 1978), $12 \mathrm{~km}$ north-northwest of Dimlington. Identical series of tests to those carried out at Dimlington were undertaken on 13 samples from four horizons through $15 \mathrm{~m}$ of till. The results of preconsolidation determinations are shown in Figure 17.

\section{Discussion}

The slopes of the linear regression lines through the Tunstall and Dimlington data are similar $\left(15.3 \mathrm{kPa} \mathrm{m}^{-1}\right.$ at Tunstall compared with $14.4 \mathrm{kPa} \mathrm{m}^{-1}$ at Dimlington) and similar to the gravitational pre-consolidation gradient $\left(11.0 \mathrm{kPa} \mathrm{m}^{-1}\right)$. However, the extrapolated value of pre-consolidation at the top of the till at Tunstall is $373 \mathrm{kPa}$ (Fig. 17a), giving a shear strength of $184 \mathrm{kPa}$ (Fig. 17b), considerably larger than at Dimlington. Thus, whereas the values of $\partial p^{\prime} / \partial z$ are similar at Tunstall and Dimlington and conform with the theory that a till of relatively high permeability should have an approximately gravitational pre-consolidation gradient, how do we explain the contrast in $p_{0}{ }^{\prime}$ between the two sites?

If the two pre-consolidation profiles were contemporary, it implies that the contemporary resistance of the subglacial tills at Holderness showed strong spatial variation, with stiff areas such as Tunstall, and soft areas such as Dimlington. A low effective pressure (high porewater pressure) at Dimlington could have been produced as a result of poor drainage from the till through the subjacent Chalk, whilst a high effective pressure (low pore-water pressure) at Tunstall could have been produced by an efficient local drainage pathway through the Chalk. Development of a less time-consuming method of determining pre-consolidation would permit regional patterns to be mapped.

An alternative explanation is that the profiles are a result of time-dependent changes. It is possible, for instance, that the profile at Tunstall was once much tnicker, that the value of $p_{0}{ }^{\prime}$ was similar to that at Dimlington, but that it has been unloaded by erosion of till (Fig. 18). Given the present value of $\partial p^{\prime} / \partial z, 20 \mathrm{~m}$ of till would need to have been eroded if the original value of $p_{0}{ }^{\prime}$ was the same as at Dimlington (Fig. 18). If we assume that erosion of till only takes place when the shear resistance of the till is less than the Coulomb failure criterion, and that the basal shear stress was similar to

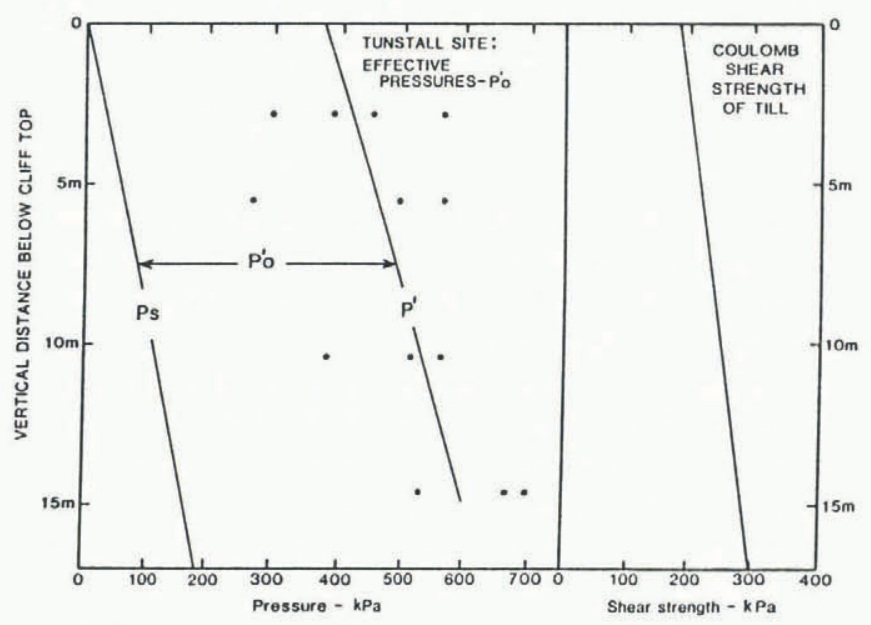

Fig. 17. The Tunstall site. (a) Determinations of preconsolidation pressure. The vertical pre-consolidation gradient is approximately gravitational, as at Dimlington, although pre-consolidation values are much larger. (b) Shear strength calculated from the values of $p^{\prime}$ in (a) and $\phi=24^{\circ}$ and $C^{\prime}=18 \mathrm{kPa}$. 
that at Dimlington, $p_{0}{ }^{\prime}$ could not have exceeded 22.5$60 \mathrm{kPa}$ during the erosion process.

It is important to note that experimentally determined pre-consolidation values reflect the largest effective pressures to which the tills have been subjected. During the erosion process (Fig. 18), $p_{0}{ }^{\prime}$ and $\partial p^{\prime} / \partial z$ could have remained constant, resulting in lowering of effective pressures below the pre-consolidation values at any horizon. A similar situation could have occurred at the Marum site.

At a site where pre-consolidated sediment is actively being eroded, sediment is removed in a deforming horizon at low effective pressure. At some sites, we might expect a remnant of this deforming mass represented by a thin, lightly overconsolidated horizon above more heavily overconsolidated till.

If, as Boulton and Hindmarsh (1987) have suggested, effective pressures at the glacier sole tend to have low values which permit stable deformation of fine-grained subglacial sediment, the value of the vertical preconsolidation gradient $\left(\partial p^{\prime} / \partial z\right)$ and its magnitude at the top of the sequence $\left(p_{\mathrm{t}}{ }^{\prime}\right)$ would permit an estimate of the thickness of sediment $\left(t_{\mathrm{e}}\right)$ which has been eroded subglacially. This will be:

$$
t_{\mathrm{e}}=\frac{p_{\mathrm{t}}{ }^{\prime}}{\partial p^{\prime} / \partial z} .
$$

The geological reconstruction of the Devensian ice lobe down the eastern coast of England has long been difficult to explain. Elongate lobes occur in mountain

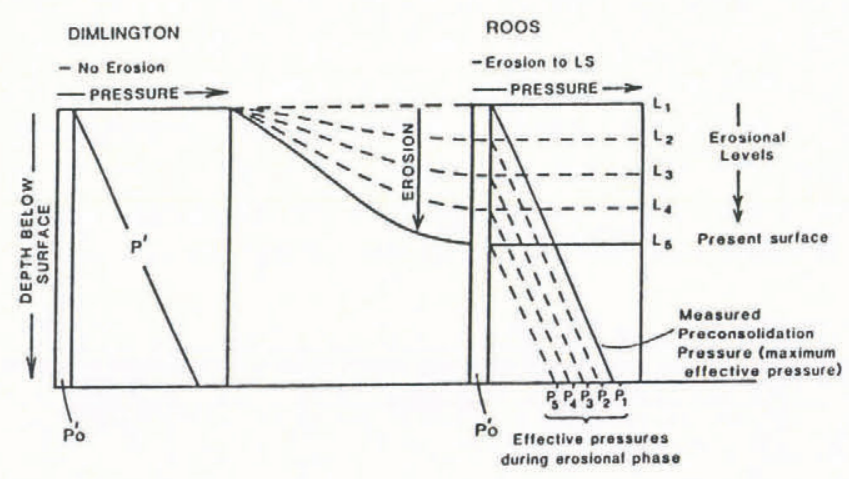

Fig. 18. Schematic diagram explaining the difference in vertical pre-consolidation profiles between the Dimlington and Tunstall sites. The effective pressure at the glacier sole $\left(p_{0}{ }^{\prime}\right)$ will have a low value to permit continuous deformation. The gradient of effective pressure with depth will show an approximately gravitational gradient due to the relatively high permeability of the till. It is assumed that the till at Dimlington is at its maximum thickness and has not been eroded since. The preconsolidation pressure we now measure is therefore appropriate to the till thickness. It is suggested that the till at Tunstall has been eroded below its maximum thickness, that the measured pre-consolidation profile reflects this maximum thickness and has been truncated by erosion. During erosion, through stages $L_{1}$ to $L_{5}$, the effective pressures have changed from $p_{1}{ }^{\prime}$ to $p_{5}{ }^{\prime}$, below the measured pre-consolidation value. Thus, the pre-consolidation profile may be an index of till erosion. valleys but development of an elongate lobe on a flat bed requires a longitudinal gradient which is much less than the lateral gradients. This could be explained if we assume that the eastern England glacier lobe had a similarly low basal shear stress to that inferred at Dimlington wherever it lay on soft sediments of low permeability, and that there was a basal shear stress typical of a glacier flowing over a rigid substratum where it mounted the Chalk uplands of the Yorkshire/Lincolnshire Wolds. However, the eastern flank must also have a steep profile and, as yet, we lack sufficient information about the sub-till sequence in the western North Sea to determine whether an explanation similar to that of the western flank of the east Yorkshire lobe is appropriate.

\section{RANGE OF CONSLIDATION/SHEARING STATES IN SUBGLACIAL SEDIMENTS}

The state of consolidation of subglacial sediments and their propensity to deform in response to the shear force imposed by the moving glacier are related to:

The basal melting rate.

The distribution of subglacial permeability and the ease with which aquifers drain into the proglacial environment.

The effective pressure-dependent flow law for the sediments.

The extent of the glacier.

Figure 8 shows four end-members of a continuous series of situations in which the pattern of pre-consolidation and the distribution of deformation in a subglacial aquitard/till are shown in relation to its permeability and the effectiveness of drainage.

\section{Fig. 8A. Relatively high-permeability till underlain by aquifer drain}

High aquifer transmissibility ensures that aquifer potential $\left(\psi_{\mathrm{a}}\right)$ is low and $p_{\mathrm{a}}{ }^{\prime}$ is high. Relatively high till permeability ensures that $\partial p^{\prime} / \partial z$ is approximately gravitational $\left(\partial p^{\prime} / \partial z\right)_{\mathrm{g}}$. Therefore, $p_{0}{ }^{\prime}>p_{\mathrm{c}}{ }^{\prime}$ and the till will not deform.

\section{Fig. 8B. Low-permeability till underlain by aquifer drain}

High aquifer transmissibility ensures low $\psi_{\mathrm{a}}$ and high $p_{\mathrm{a}}{ }^{\prime}$. But low till permeability gives $\partial p^{\prime} / \partial z \gg\left(\partial p^{\prime} / \partial z\right)_{\mathrm{g}}$ so that the upper part of the till deforms $\left(p^{\prime} \leq p_{\mathrm{c}}{ }^{\prime}\right)$.

\section{Fig. 8C. Relatively high-permeability till underlain by aquiclude}

Case 1 (small glacier). Transmissibility of till is alone enough to discharge meltwater at low potential gradient so that $p^{\prime}<p_{\mathrm{c}}{ }^{\prime}$. No deformation and $\left(\partial p^{\prime} / \partial z\right)$ $\approx\left(\partial^{\prime} / \partial z\right)_{\mathrm{g}}$. 
Fig. 8D. Low-permeability till underlain by aquiclude

Low till permeability requires a large potential gradient to discharge meltwater. $p^{\prime}<p_{\mathrm{c}}{ }^{\prime}$ throughout so that the till deforms throughout. As water flow is horizontal, $\partial p^{\prime} / \partial z$ is gravitational. If the till is very thick, the lowest part may escape deformation. As $p_{0}{ }^{\prime}$ will tend to zero, channel formation at the glacier-bed interface will occur to ensure that $p_{0}{ }^{\prime} \geq 0$, by drawing down water pressures so that unstable deformation does not occur (Boulton and Hindmarsh, 1987).

Figure 19 summarizes the control exerted by till permeability and sub-till drainage on the pre-consolidation of till and the depth of deformation within it. The extreme cases listed above and shown in Figure 8 occur at the four corners of the field. Large pre-consolidation gradients will tend to occur where tills (or other immediately subglacial sediments) are of low permeability and have good subjacent drainage (condition a). Deformation will tend not to occur where till permeability is high and subjacent drainage is good (condition b). The greatest depth of deformation will occur where till permeability is low and there is no subjacent drainage.

Figure 19 also suggests positions for two modern glacier sites where conditions are more or less well known. The Breidamerkurjökull site in Iceland (Boulton and

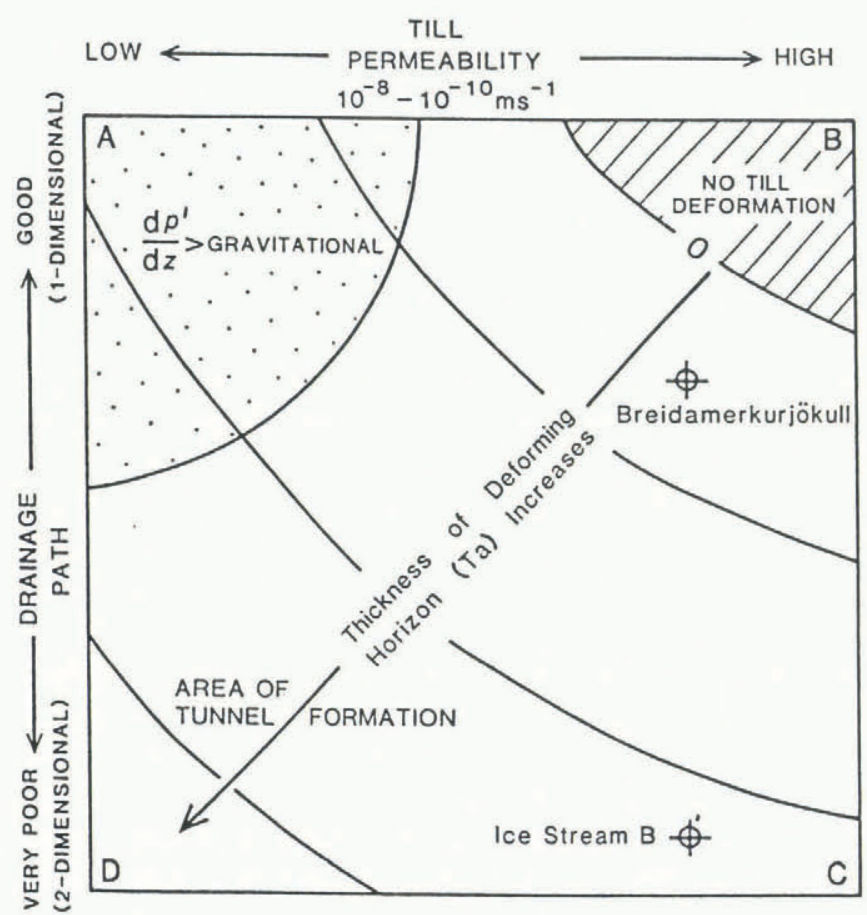

Fig. 19. The effect of till permeability and sub-till drainage on subglacial consolidation and deformation. In area $B$ of high till permeability and good drainage there is no till deformation. As permeability decreases and drainage deteriorates, the thickness of the deforming horizon increases and tunnels tend to develop (area $D$ ), so as to drain the till and maintain stable deformation. In area $A$, of low till permeability and good sub-till drainage (onedimensional case), the vertical effective pressure gradient is significantly greater than gravitational (stippled area).
Hindmarsh, 1987) has a relatively permeable till, good underlying drainage and a thin deforming layer $(0.5 \mathrm{~m})$. The Ice Stream B site in Antarctica (Alley and others, 1987) appears to have a relatively permeable till (Kamb and others, 1990), probably little sub-till drainage and a deforming-layer thickness of 10-20 m.

It is not implied that subglacial tunnels will only exist where condition d (Fig. 8) is satisfied. Tunnels may form at other localities, for instance where the glacier sole lies directly on bedrock, and continue to transport water through any of the other zones, or form under condition d and transport through any of the others.

Case $d$ is particularly interesting. If the till deforms throughout, it will slide over underlying bedrock and can be expected to erode it. It is the condition inferred from geological evidence by Gjessing (1960), who suggested that a slurry-like till deforming over a bedrock surface could produce so-called plastic scouring forms (Dahl, 1965) on bedrock.

The thickness of the deforming A horizon $\left(t_{\mathrm{A}}\right)$ will be

$$
t_{\mathrm{A}}=\frac{p_{\mathrm{c}}{ }^{\prime}}{\left(\partial p^{\prime} / \partial z\right)_{\mathrm{g}}} .
$$

For a basal shear stress of $\tau_{\mathrm{b}}=50-100 \mathrm{kPa}$, a typical value of $p_{\mathrm{c}}{ }^{\prime}$ will be $100-300 \mathrm{kPa}$. Using $10 \mathrm{kPa} \mathrm{m}^{-1}$ as a typical value of $\left(\partial p^{\prime} / \partial z\right)_{g}, t_{\mathrm{A}}$ will be $10-30 \mathrm{~m}$. Thus, a till less than $10 \mathrm{~m}$ in thickness overlying impermeable bedrock will tend to deform throughout, and thereby erode underlying bedrock. The tills described by Gjessing (1960) are indeed thin and overlie impermeable bedrock, and would be expected to erode as he suggested.

\section{Time-dependence}

The pore-water pressures in clays of low permeability will take a significant time period to equilibrate to external changes in water-discharge rate or pressure. As has been shown by Boulton and Hindmarsh (1987), this can be of the order of $10^{3}$ year in sediments of very low permeability such as the Peelo Clays. It is possible, therefore, that the measured pre-consolidation pressures and gradients do not reflect conditions at the Saalian glacial maximum, unless this was sustained for the order of $10^{3}$ year, but a minimum estimate of thickness at the glacial maximum.

No such problems occur in the case of the Dimlington tills whose permeability is very much higher, with a response time of less than 10 years.

\section{Implications for studies of ancient glaciation}

(a) In general, it is not possible to calculate former ice thicknesses directly from single-horizon measurements of the state of pre-consolidation of fine-grained sediments as some have suggested (e.g. Bernhard, 1963). We do suggest, however, that ice thickness and some other important characteristics of former glaciers can be determined from geotechnical measurements, provided that hydrogeological geometry is sufficiently well-defined.

(b) In view of the difficulties of monitoring contemporary subglacial hydrology, the characteristics of 
ancient glacial sediments can help us to understand general attributes of subglacial hydrology.

(c) The hydrological conditions conducive to subglacial sediment deformation are widespread in areas of former glaciation. We would thus expect that in lowland areas where abundant sediment is available, erosion, sediment transport and till formation as a result of subglacial deformation will be the norm rather than the exception.

\section{DEDICATION AND ACKNOWLEDGEMENTS}

This paper is dedicated to Professor Louis Lliboutry on his retirement. He has contributed greatly to our understanding of water flow at the base of glaciers and the authors hope that he might be amused by the thought of water in subglacial sediments 150000 years ago.

We thank Dr F. Schokking and the Dutch Geological Survey, Haarlem, for access to and help with Peelo Clay sampling, our colleague Dr R. Hindmarsh, for valuable discussions and an anonymous refereee for very helpful comments.

\section{REFERENCES}

Alley, R. B., D. D. Blankenship, C. R. Bentley and S.T. Rooney. 1987. Till beneath Ice Stream B. 3. Till deformation: evidence and implications. 7. Geophys. Res., 92(B9), 8921-8929.

Bernhard, H. 1963. Der Drucksetzungsversuch als Hilfsmittel zur Ermittlung der Mächtigkeit des pleistozänen Indlandseises in Nordwest-Niedersachsen. Technische Hochschule Hannover. Geologisches Institut. Mitteilungen 1.

Bodvarsson, G. 1955. On the flow of ice-sheets and glaciers. Jökull, 5, 1-8.

Boulton, G. S. and R. C. A. Hindmarsh. 1987. Sediment deformation beneath glaciers: rheology and geological consequences. F. Geophys. Res., 92(B9), 9059-9082.

Boulton, G.S. and A.S. Jones. 1979. Stability of temperate ice caps and ice sheets resting on beds of deformable sediment. F. Glaciol., 24(90), 29-43.

Boulton, G.S., D. L. Dent and E.M. Morris. 1974. Subglacial shearing and crushing, and the role of water pressures in tills from south-east Iceland. Geogr. Ann., 56A(3-4), 135-145.

Boulton, G.S., A.S. Jones, K. M. Clayton and M.J. Kenning. 1977. A British ice-sheet model and patterns of glacial erosion and deposition in Britain. In Shotton, F. W., ed. British Quaternary studies. Oxford, Clarendon Press, 231-246.

British Standards Institution. 1975. British standard methods of test for soils for civil engineering purposes. London, British Standards Institution. (BS 1377.)
Casagrande, A. 1936. The determination of the preconsolidation load and its practical significance. In First International Conference on Soil Mechanics and Foundation Engineering, 60-64.

Catt, J.A. 1977. Yorkshire and Lincolnshire field guide. International Union for Quaternary Research, 10th Congress. Norwich, Geoabstracts.

Catt, J.A. and L.F. Penny. 1966. The Pleistocene deposits of Holderness, east Yorkshire. Proc. Yorks. Geol. Soc., 35, 375-420.

Dahl, R. 1965. Plastically sculptured detail forms on rock surfaces in northern Nordland, Norway. Geogr. Ann., 47A (2), 83-140.

Foster, C.T. 1983. Geotechnical properties and origin of the till of Holderness, N.E. England. (Ph.D. thesis, University of Keele.)

Gjessing, J. 1960. Isavsmeltningstidens drenering, dens forløp og formdannende virkning i Nordre Atnedalen. Ad Novas. Skrifter fra Det Norske Geografiske Selskab. 3.

Hindmarsh, R. C. A., G. S. Boulton and K. Hutter. 1989. Modes of operation of thermo-mechanically coupled ice sheets. Ann. Glaciol., 12, 57-69.

Jacob, C. E. 1940. On the flow of water through an elastic artesian aquifer. Transactions of the American Geophysical Union, 2, 574-586.

Kamb, B. and others. 1990. Is the Antarctic ice sheet disintegrating? Eng. Science, 53(3), 5-13.

Khera, R.P. and H. Schulz. 1984. Past consolidation stress estimates in Cretaceous clay. A.S.C.E.F. Geotech. Eng., 110, 189-202.

MacDonald, A. B. and E. K. Sauer. 1970. The engineering significance of Pleistocene stratigraphy in the Saskatoon area, Saskatchewan, Canada. Can. Geotech. J., 7(2), 116-126.

Madgett, P.A. and J. A. Catt. 1978. Petrography, stratigraphy and weathering of late Pleistocene tills in east Yorkshire, Lincolnshire and north Norfolk. Proc. Yorks. Geol. Soc., 42, 55-108.

Penny, L. F., G. Coope and J. Catt. 1969. Age and insect fauna of the Dimlington silts, east Yorkshire. Nature, 224, 65-67.

Saur, E. K. and E. A. Christiansen. 1988. Preconsolidation pressures in an intertill glaciolacustrine clay near Blain Lake, Saskatchewan. Can. Geotech. 7., 25, 831839.

Schokking, F. 1990. A sub-glacial sediment deformation model from geotechnical and structural properties of an overconsolidated lacustro-glacial clay. Geol. Mijnbouw, 69(3), 291-304.

Vialov, S. W. 1958. Regularities of glacial shields movement and the theory of plastic viscous flow. International Association of Scientific Hydrology Publication 47 (Symposium at Chamonix 1958 - Physics of the Movement of the Ice), 266-275.

The accuracy of references in the text and in this list is the responsibility of the authors, to whom queries should be addressed. 